This PDF is a selection from an out-of-print volume from the National Bureau of Economic Research

Volume Title: NBER Macroeconomics Annual 1989, Volume 4

Volume Author/Editor: Olivier Jean Blanchard and Stanley Fischer, editors

Volume Publisher: MIT Press

Volume ISBN: 0-262-02296-6

Volume URL: http://www.nber.org/books/blan89-1

Conference Date: March 10-11, 1989

Publication Date: 1989

Chapter Title: Recent Trends in U.S. Earnings and Family Incomes

Chapter Author: Frank Levy

Chapter URL: http://www.nber.org/chapters/c10963

Chapter pages in book: (p. 73 - 120) 
Frank Levy ${ }^{1}$

UNIVERSITY OF MARYLAND

\section{Recent Trends in U.S. Earnings and Family Incomes}

\section{Introduction}

In his recent survey of economic growth, Angus Maddison (1987) referred to "the postwar golden age which ended in 1973 . . . (p. 649)." Maddison was discussing the growth of GDP but his description applies equally well to the growth of individual incomes. Since 1973, industrialized countries have faced the income losses of two oil price shocks and experienced sharp slowdowns in the growth of multi-factor and labor productivity.

The impact of these events can be understood by considering the stylized frontier that describes the point-in-time trade-off between the growth rate of employment and the growth of the marginal product of labor (Figure 1). For most countries, the decline in labor productivity growth shifted the frontier inward. The oil price shocks had a similar, but more episodic, effect by raising import prices and so reducing the purchasing power of the product wage.

Different countries dealt with their newly restricted choices in different ways. Many European economies continued to enjoy real wage growth at the cost of historically high unemployment (Blanchard and

1. School of Public Affairs, Morrill Hall, University of Maryland, College Park, Maryland 20742. 301-454-7242. This paper is an extension of two earlier papers: "Incomes, Families, and Living Standards," Chapter 4 in Robert E. Litan, Robert Z. Lawrence, and Charles L. Schultze (eds.), American Living Standards: Challenges and Threats (Brookings Institution, 1988) and "Earnings and Education: Recent U.S. Trends" (with Richard Michel), paper prepared for the Joint Economic Committee of the U.S. Congress, forthcoming, 1989). The author wishes to thank Patrick Purcell of the Urban Institute for extensive research assistance, Carol Newman of the Brookings Institution for programming assistance and Stanley Fischer, Robert Lawrence, Richard Michel, Kevin Murphy, Charles Schultze, and Larry Summers for comments on various drafts. He also wishes to thank the Ford Foundation, the Urban Institute and the Brookings Institution for financial support. 
Figure 1 THE TRADE-OFF BETWEEN THE GROWTH RATE OF EMPLOYMENT AND THE GROWTH RATE OF LABOR'S MARGINAL PRODUCT

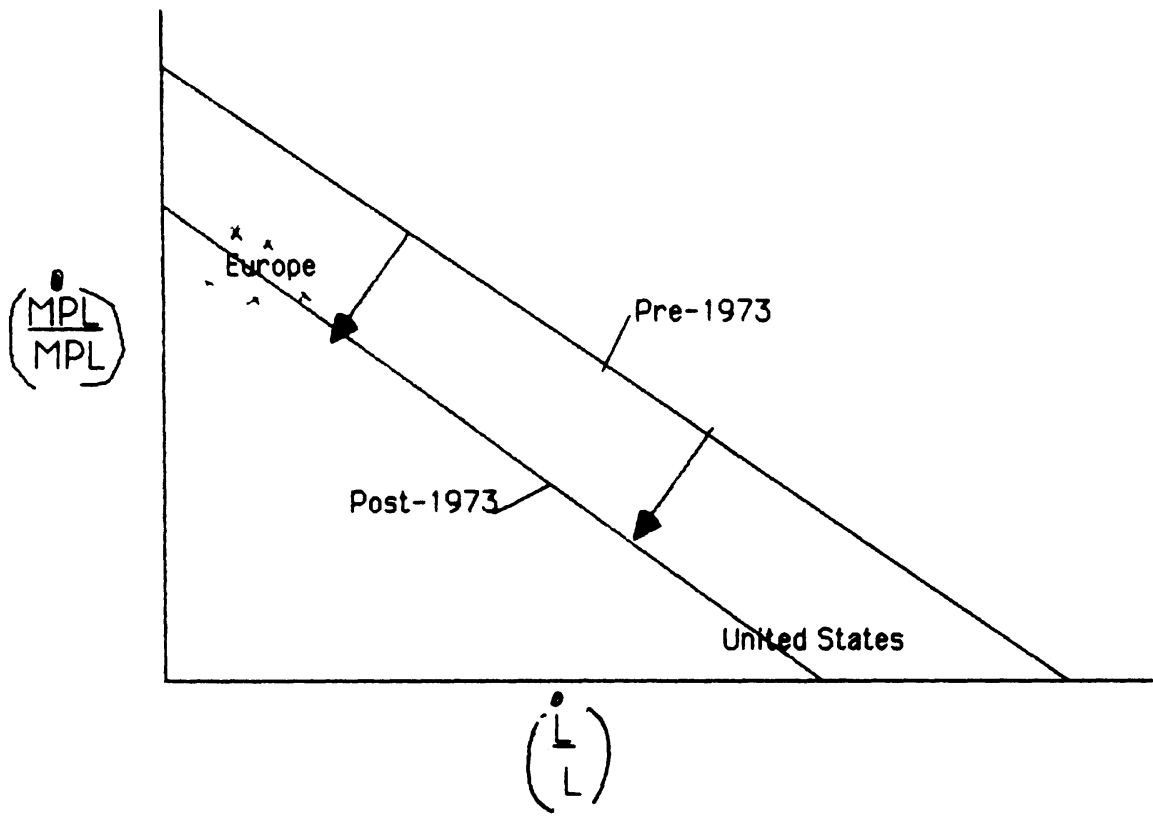

Summers 1986; and Lawrence and Schultze 1987). In the United States, civilian employment increased by 24.5 million persons $(+29 \%)$ between 1973 and 1986 but at the cost of very low real wage growth. ${ }^{2}$ In the U.S., moreover, general wage stagnation was accompanied by greater inequality in annual earnings for men (but not for women) and greater inequality in family incomes.

The combined effect of stagnant wages and greater inequality on U.S. men's earnings is displayed in Figure 2 which compares annual earnings distributions of prime age men (ages 25-55) for 1973 and 1986. The data, taken from the Current Population Survey (CPS), refer to pre-tax money earnings (the CPS records neither taxes nor fringe benefits) and the sample consists of men who worked at least one hour during the year. ${ }^{3}$

2. The reader may ask whether the increase in U.S. employment is, by itself, sufficient to explain low wage growth without appeal to the restricted frontier of Figure 1. I discuss this question in Section 2.

3. For purposes of this paper, earnings are defined as the sum of CPS items measuring an individual's wage and salary income, self-employment income and farm income. Where this sum is negative (reflecting business losses among the self-employed), it has been arbitrarily reset to $\$ 1.00$. 
Figure 2 EARNINGS OF 25-55-YEAR-OLD MEN: 1973, 1986 (MEN AGE 25-34 WITH 12 OR FEWER YEARS OF EDUCATION SHOWN IN SUBBARS)

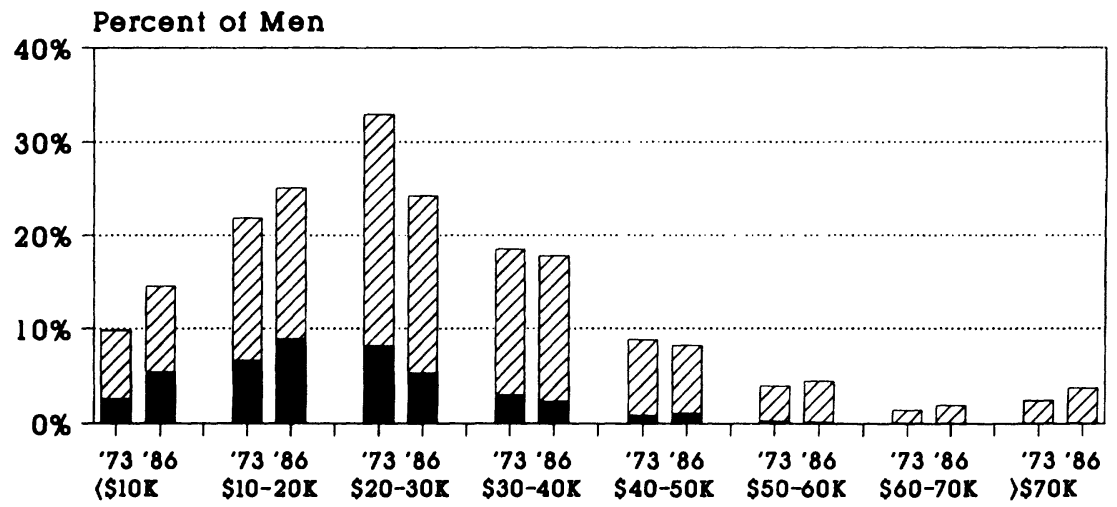

Earnings Bracket

25-34, L.E. 12 yrs एZA All Other Men

Earnings in 1987 dollars. Inflation-adjusted using PCE Index.

The data, like all other income data in this paper, are expressed in 1987 dollars using the implicit Personal Consumption Expenditure Deflator of the Gross National Product Accounts.

Had real wages grown at, say, $2 \%$ per year after 1973, the 1986 distribution in Figure 2 would have been centered in the $\$ 30-\$ 40,000$ range. ${ }^{4}$ In the absence of such growth, the 1973 and 1986 distributions overlap to a substantial degree and the overlap facilitates intertemporal comparisons. When 1973 and 1986 are compared, the proportion of men earning less than $\$ 20,000$ and earning more than $\$ 50,000$ have both increased while the proportion of men earning $\$ 20-\$ 50,000$ has declined. In the language of popular debate, these changes in the distribution of male earnings are consistent with either of two meanings of vanishing middle class jobs: an increased inequality of earnings (resulting in a distribution with a smaller middle class), and a declining proportion of workers who

4. For example, in the 13 years from 1960 to 1973 , labor productivity in the non-farm business sector grew at an average $2.4 \%$ per year and the median individual income of all men who worked year-round and full-time increased from $\$ 19,638$ to $\$ 27,490$ (in 1987 dollars) $(+40 \%)$ (Bureau of the Census, 1987b). The conjectural $2 \%$ figure in the text reflects the fact that under the best of conditions, the growth of output per worker would have been depressed by the entrance of the baby boom cohorts into the labor force. 
earn enough to support a middle class standard of living-e.g., above $\$ 20,000$. $^{5}$

Figure 3 compares the 1973 and 1986 annual earnings distributions of prime age women (ages 25-55). Here, a quite different picture emerges. Women's annual earnings lie well below mens', but between 1973 and 1986 , the proportion of women earning less than $\$ 10,000$ has declined substantially while the proportion earning between $\$ 20$ and $\$ 50,000$ has increased.

A number of popular articles have drawn direct links between shifts over time in the real earnings distribution and the movement of labor between middle class, or "good jobs" (high wage jobs) and "bad jobs" (low wage jobs). ${ }^{6} \mathrm{~A}$ moment's reflection suggests several other reasons why real earnings distributions may shift: changes in the age/education composition of the population, changes in the number of hours worked, changes in cohort size. Further, all of these factors operate in a context established by the underlying growth of productivity and macroeconomic shocks.

Figure 4 compares the 1973 and 1986 family income distribution. The Census defines a "family" as two or more persons related by blood, marriage, or adoption. Persons who live alone or cohabit with nonrelatives are excluded from the distribution. ${ }^{7}$ The resulting family distribution depends in part on individual earnings and in part on the number of earners per family, as well as the distribution of income sources other than earnings including interest, dividends, rents, private pensions, and government pensions and transfer payments. (Note, however, that the CPS does not record income from capital gains.)

In the family income distribution, as in the distribution of prime-age male annual earnings, there has been little real growth between 1973 and 1986 . Over the period, median family income increased from $\$ 28,890$ to $\$ 30,670$ ( $5 \%$ per decade), a far slower rate than in earlier decades. ${ }^{8}$ And as

5. The debate was prominent in the 1988 presidential campaign and included Michael Dukakis' references to "good jobs at good wages" and "two-paycheck prosperity," Richard Gephardt's commercial featuring the " $\$ 48,000 \mathrm{~K}-\mathrm{Car}$," Jesse Jackson's speeches on the victims of "economic violence" and Pat Robertson's speeches to South Carolina textile workers in which he argued that their industry was being destroyed by international bankers.

6. These articles are referenced in Section 3.

7. In Census statistics, these persons are included in a separate income distribution of "unrelated individuals."

8. These figures are from the U.S. Bureau of the Census (1987b) but they are adjusted by the implicit PCE deflator rather than the Consumer Price Index (CPI) used by the Census. CPI adjustment would show median family income declining by $1 \%$ per decade. I discuss family income growth in Section 5. 
in the distribution of male earnings, stagnation of family incomes was accompanied by greater income inequality. During the period, the proportions of families with incomes below $\$ 10,000$ and above $\$ 50,000$ both increased moderately while the proportions of families with incomes between $\$ 10,000$ and $\$ 50,000$ declined moderately.

In this paper, I review recent trends in the level and distribution of individual earnings and family incomes in the United States. The remainder of the paper is divided into six sections. In Section 2, I review the trend in individual incomes for the post-World War II period. The trend is one of significant income growth through 1973 followed by very slow growth (i.e., stagnation) thereafter. I discuss some of the implications of the transition from growth to stagnation for U.S. life. In Section 3, I examine detailed post-1973 wage and earnings trends for selected demographic groups to see why some groups' earnings grew faster than the underlying trend while other group's earnings grew more slowly. Much of the growing "lower tail" in Figure 2 reflects the declining earnings of young, less educated men. By contrast, some of the upward shift in Figure 3 reflects higher hourly wages for college educated women. I propose an explanation of these trends based

Figure 3 EARNINGS DISTRIBUTION OF WOMEN (EARNINGS IN 1973 AND 1986; WOMEN 25-45 WITH 4 YEARS COLLEGE SHOWN IN SUBBARS)

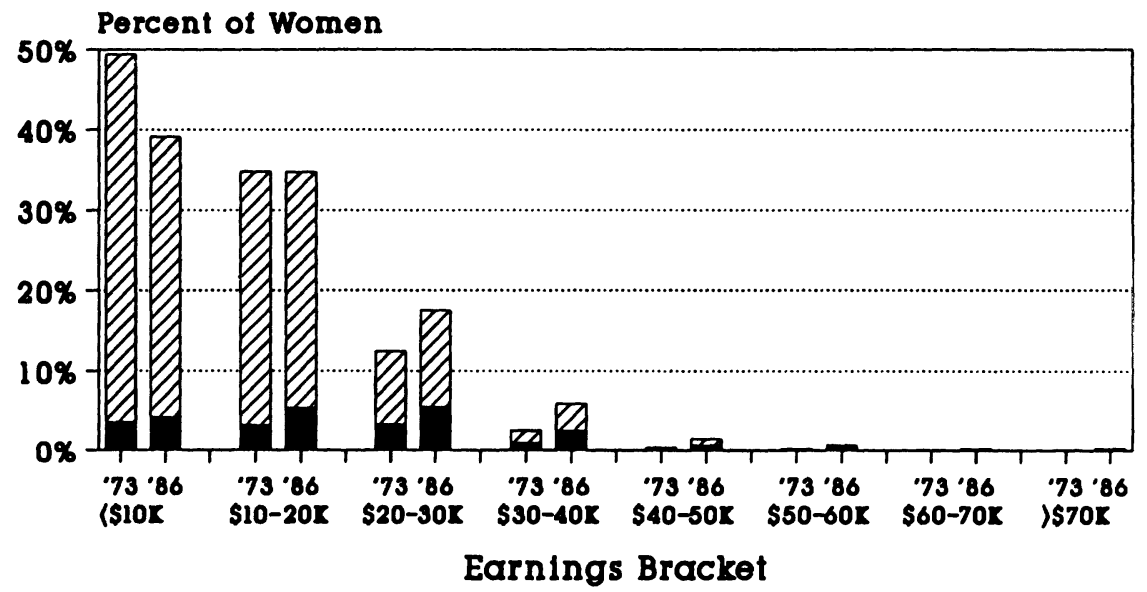

25-45, 4 yrs. coll. VIA All Other Women 
largely on shifts in the demand for different kinds of labor. Together, the detailed statistics and the explanation help clarify the good jobs-bad jobs debate.

In Section 4, I briefly sketch how the nation managed to increase per capita income, a traditional measure of living standards, even as earnings stagnated.

In Section 5, I review recent changes in the family income distribution. Family income inequality has increased to a degree but equally important are movements of various groups within the distribution. In a context of slow family income growth and moderately increasing inequality, the position of elderly families has improved significantly while the position of the poorest one-third of children has declined sharply.

In Section 6, I examine parts of the process by which changes in men's earnings inequality are transformed into changes in family income inequality. The complete transformation is complex and depends upon the distribution of unearned income, the propensity to marry, the propensity of married men to have working spouses, and the relationship between low male wages and the formation of female-headed families. I present some rough calculations on the first three items in this list.

Section 7 contains a short conclusion and some speculations on the future.

Figure 4 DISTRIBUTION OF FAMILIES BY INCOME 1973, 1986

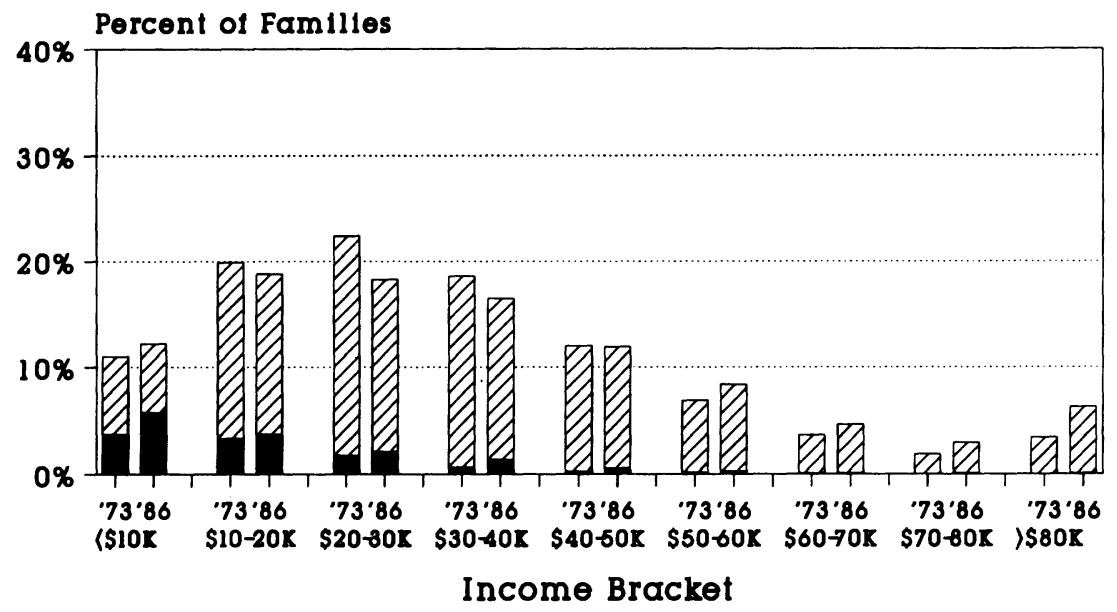

Female Headed VIA All Other Familles

Income in 1987 dollars. Inflation-adjusted using PCE Index. 


\section{Earnings Growth and Stagnation.}

A standard analytical tool in labor economics is the age-earnings profile, the relationship between earnings and age in a cross-sectional sample. The profile shows how earnings change with increased experience. But as a man or woman actually ages, changes in earnings will arise from two general effects. The first is the movement along the age-earnings profile, the effect of increased experience. The second is the effect of changes in the economy's real wage scale which can move the entire age-earnings profile up or down.

In periods of strong real wage growth, the second effect dominates the first through much of a man's career. Consider the cohort of men who were 35-44 in 1949 (Figure 5). The CPS reports the median income of

Figure 5 THE GROWTH OF MEN'S EARNINGS OVER TIME (1987 DOLLARS)

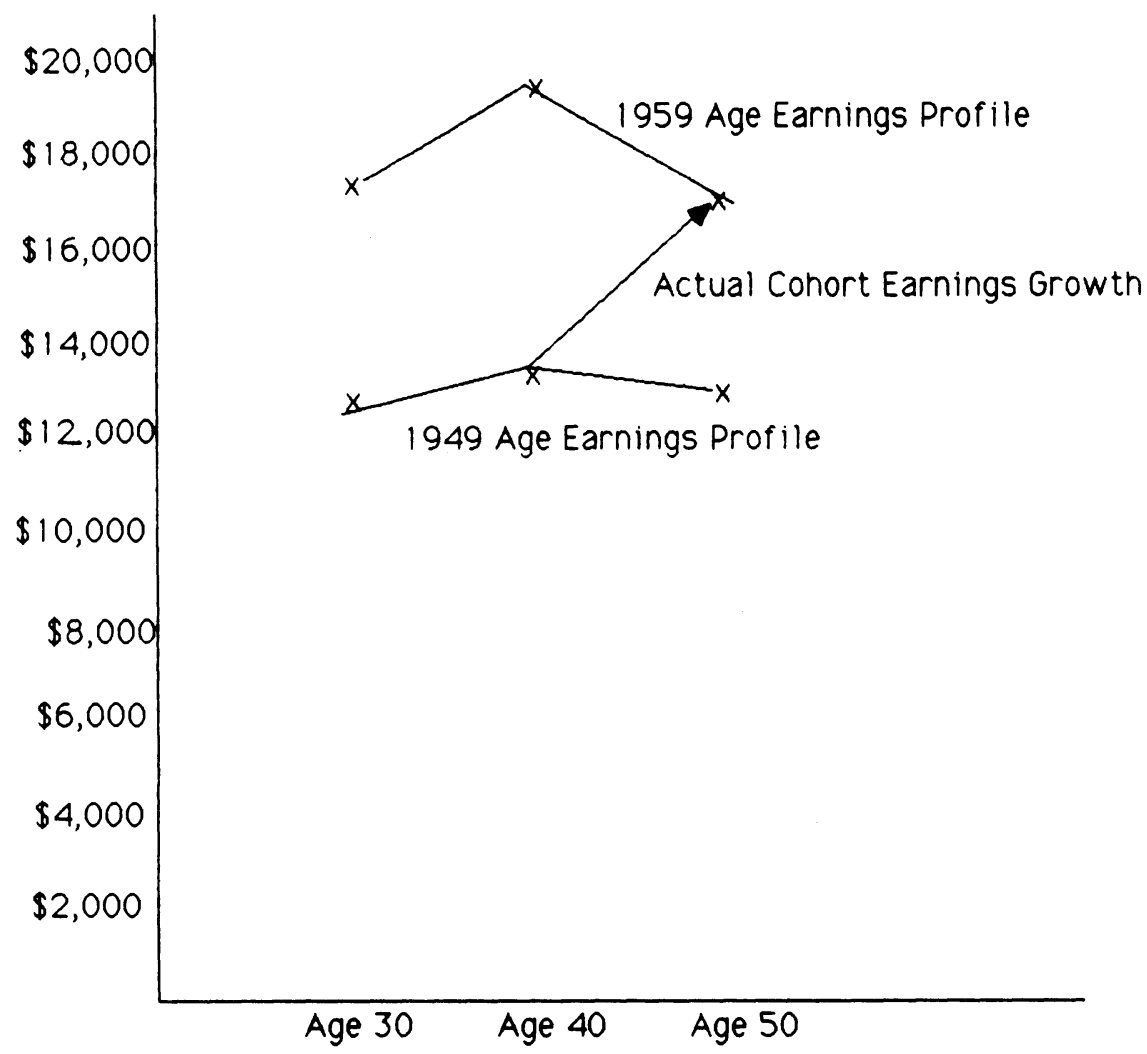

Source: Current Population Reports, Various Issues. Income at Age 30 refers to Median income of 25-34-year-old men, etc. 
Table 1 THE STAGNATION OF WORKERS' INCOMES AFTER 1973 (1987 DOLLARS)

\begin{tabular}{|c|c|c|c|c|}
\hline \multirow{2}{*}{$\begin{array}{l}\text { Men who } \\
\text { were } 50 \text { in: }\end{array}$} & \multicolumn{2}{|c|}{$\begin{array}{c}\text { Their average income } \\
\text { at age } 50 \\
\text { (Full-Time Workers Only) }\end{array}$} & \multicolumn{2}{|c|}{$\begin{array}{l}\text { Growth in the } \\
\text { income scale over } \\
\text { the previous decade }\end{array}$} \\
\hline & Census & Adjusted & Census & Adjusted \\
\hline $1946^{*}$ & $\$ 15,257$ & $\$ 15,529$ & - & - \\
\hline 1956 & $\$ 18,558$ & $\$ 19,208$ & $21.6 \%$ & $23.7 \%$ \\
\hline 1966 & $\$ 23,971$ & $\$ 25,168$ & $29.2 \%$ & $31.0 \%$ \\
\hline (1973) & $(\$ 30,578)$ & $(\$ 32,701)$ & ** & $* *$ \\
\hline 1976 & $\$ 30,179$ & $\$ 32,752$ & $25.9 \%$ & $30.1 \%$ \\
\hline 1986 & $\$ 32,960$ & $\$ 36,228$ & $9.2 \%$ & $10.6 \%$ \\
\hline
\end{tabular}

*1946 is used as a starting point because it is when the first published data were available.

**As noted in the text, the process of deep stagnation began at the end of 1973 with the first OPEC oil price shock. The growth rate of incomes between 1973 and 1987 on a per decade basis was $5.9 \%$ (Census) and $8.2 \%$ (Adjusted).

Source: Income statistics from U.S. Bureau of the Census, Current Population Reports, Series P-60, various issues. Income for adjustments from U.S. Department of Commerce, Bureau of Economic Analysis, National Income and Product Accounts, various issues. "Average Income of men at 50, Full-Time Workers Only" refers to the median income of all male year-round, full-time workers, ages $45-54$. Conversion to 1987 dollars made using the Personal Consumption Expenditure Index.

these men to be $\$ 13,706$ (in 1987 dollars) while the median income of 45 54 -year-old men in the same year was $\$ 12,777$ (in 1987 dollars). In terms of pure experience effects, the cohort of 35-44-year-old men should have seen little real income gain over the next decade. But when the cohort actually reached ages $45-54$ (in 1959) their median income was $\$ 17,860$ $(+30 \%)$, the result of a rising real wage structure. ${ }^{9}$

We can approximate the real wage scale by following an earnings benchmark over time-the median annual income of 45-54-year-old men who worked year-round and full-time (Table 1) as tabulated by the CPS. By 1987, the oldest baby-boomers (born in 1946) had not yet turned 45; so earnings of men in the 45-54-year-old age range were at least partially protected from big changes in cohort size. ${ }^{10}$ By focusing on men who work year-round and full-time, we can isolate the effects

9. In practice, the age-earnings profile for more educated workers keeps rising even after the profile for less educated workers has turned down. It follows that a small part of the increase in the example reflects the fact that the cohort of 35-44-year-old men in 1949 had higher average education than the cohort ten years older.

10. The protection is only partial because of the potential substitution between older and younger men in production. 
of rising real wages while reducing the big income variations due to changing unemployment. ${ }^{11}$

The benchmark has two problems. The CPS did not cross-classify incomes by education in the 1950s and 1960s and so some of the benchmark's growth will reflect the rising educational levels of 45-54-year-old men rather than a rising (or falling) wage scale. ${ }^{12}$ And as noted earlier, the CPS measures only income while it excludes the value of fringe benefits. In recent years, fringe benefits have become an increasing portion of compensation and for this reason, Table 1 contains two columns: income as published by the Census and Census income figures with approximate adjustments for fringe benefits. ${ }^{13}$

From 1950 to 1973, GDP per hour of work (labor productivity) grew at an average annual rate of $2.5 \%$ and provided the basis for real wage growth. In 1946 the average 50-year-old man working full-time had income of $\$ 15,257$ (Table 1 ). This benchmark rose steadily so that by 1973 , the year that ended with the first OPEC oil price shock, the average 50year-old man working full-time had income of $\$ 30,578$.

A small part of this growth reflected the increased education of 45-54year-old men. Another small part reflected the movement of men out of "bad" jobs-particularly low wage agricultural jobs-and into "good" jobs. But the gains in Table 1 were largely a macroeconomic phenomenon that affected most occupations. For example, in 1969, white men who worked as "Craftsmen and Precision Workers" had mean earnings of $\$ 22,398,16 \%$ above the real mean earnings of white men who worked as "Executives, Administrators, and Managers" in 1949 (Levy 1988a, Table 7.2).

At the end of 1973, the first oil price shock led immediately to unanticipated inflation and recession in the U.S. and by 1975, the Census benchmark had fallen by about $3 \% .{ }^{14}$ More important, 1973 marked the

11. CPS volumes in the 1950s and 1960s did not contain detailed earnings data and so Table 1 is based on individual incomes (which include interest and dividends, unemployment compensation, etc.). Among middle aged men who work year-round full-time, median income is a reasonably good approximation of median earnings.

12. I use the term rising wage scale to describe a situation in which workers with a given set of demographic characteristics are paid a higher hourly compensation than similar workers earned at an earlier time.

13. These corrections are made by inflating Census estimates of median individual income by the ratio of Other Labor Income (which includes employer contributions for private fringe benefits) to Wage and Salary Income where both figures are taken from the National Income and Product Accounts.

14. Median incomes for all 50-year-old men (as distinct from full-time workers) fell more sharply because unemployment rose sharply in the 1974-75 recession. 
beginning of the sharp slowdown in the growth of multi-factor and labor productivity. ${ }^{15}$

The income loss from the 1973-74 oil price shock followed by slowgrowing productivity meant that the benchmark did not regain its 1973 level until 1979. Then the Iranian revolution triggered the second major OPEC oil price increases and the cycle of unanticipated inflation and recession began again. ${ }^{16}$ Between 1973 and 1986, the CPS benchmark grew by $5.9 \%$ per decade compared to $20-30 \%$ per decade in the 1950 s and 1960s. Total compensation increased faster than wages and salaries as employers paid higher social security taxes and health insurance premiums. But when the benchmark is adjusted for these benefits, it grew by $8.2 \%$ per decade between 1973 and 1986, less than one-third of its earlier growth rate.

The role of rising labor productivity in earnings gains is easy to accept. The precise sources of earnings stagnation are more controversial. In Section 1, I argued that the post-1973 productivity slowdown worsened the trade-off between employment growth and the growth of labor's marginal product. The reader may ask whether slow-growing U.S. earnings reflected nothing more than rapid employment growth per se: that in Figure 1, the U.S. simply moved to the upper left on the pre-1973 frontier. ${ }^{17}$

Two kinds of evidence argue against this view. The first are the estimates of Kendrick (1984) and Denison (1985) that rapid post-1973 growth in the U.S. labor force (including declining labor force experience) accounts for only about . $2 \%$ of a $1.5 \%$ slowdown in the annual growth of labor productivity. The second is the international nature of the productivity slowdown in which the growth of multi-factor and labor productivity growth slowed sharply after 1973 even in countries without rapid labor force growth (Denison 1985; Maddison 1987). In sum, the slowdown of productivity growth exerted independent downward pressure on U.S. real wages above and beyond the pressure of growing employment.

A second argument is that employee compensation has grown slowly because income is increasingly going to owners of property via interest payments, dividends, etc. Figure 6, originally prepared by the Joint Economic Committee (JEC) shows that before 1980, the growth of compensa-

15. Maddison (1987) presents the following estimates for the annual growth of joint factor productivity: U.S., $2.14 \%$ (1950-73), .52\% (1973-84); Japan, $5.79 \%$ (1950-73), $1.21 \%$ (1973-84); Germany, $4.32 \%$ (1950-73), 1.55\% (1973-84); United Kingdom, $2.14 \%$ (1950$73), 1.22 \%$ (1973-84). The growth of labor productivity per se fell in a parallel fashion.

16. More precisely, the 1979-80 oil price shock added unanticipated inflation to what was already a high rate of anticipated inflation.

17. This is equivalent to saying (as some people do) that the current slow growth in the U.S. labor force will auomatically bring an end to the productivity slowdown. 
Figure 6 PRODUCTIVITY (BOX) AND REAL COMP(CROSS)

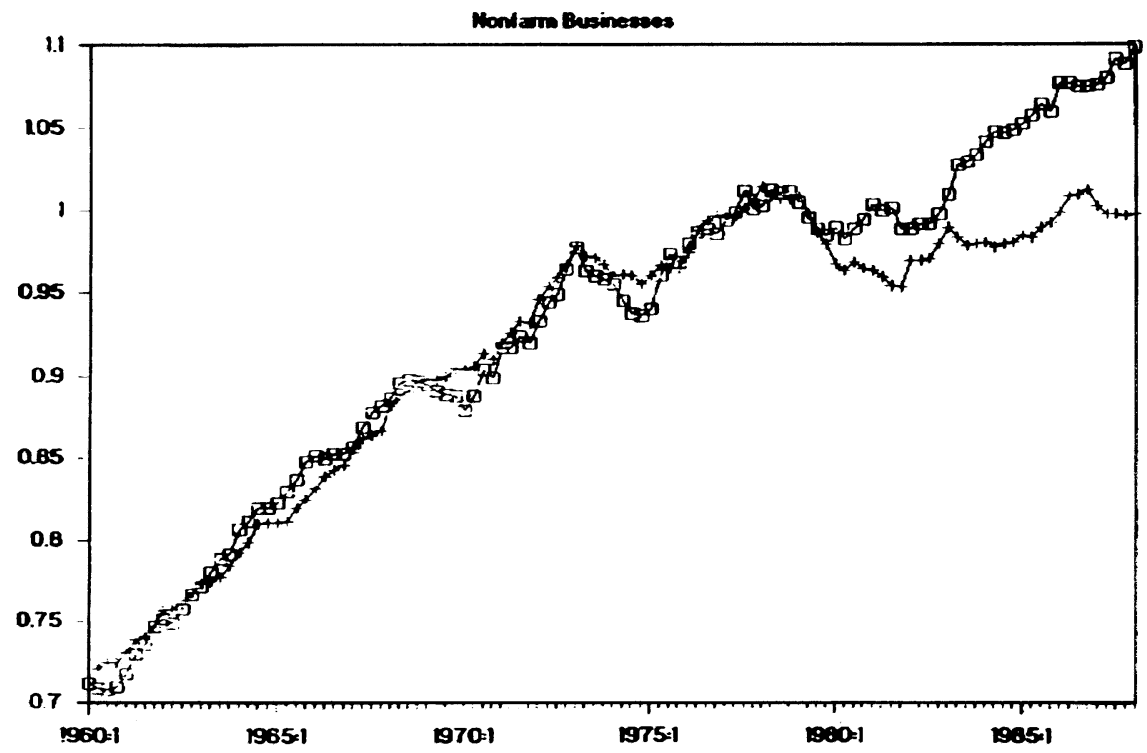

Source: Joint Economic Committee

tion per hour closely tracked the growth of GNP per worker, but that since 1980, the compensation series has lagged behind the output series. ${ }^{18}$ The biggest part of this divergence reflects the post-1980 difference between the GNP deflator (used to adjust GNP) and the CPI-X1 (used to adjust compensation). ${ }^{19}$ At the same time, compensation's nominal share of GNP did fall from .385 in 1980 to .370 in 1986 while the share of property income (in particular, interest payments) rose correspondingly. The point is that over moderately long periods, rising output per worker is a necessary, but not sufficient, condition for rising real wages. This is most evident in the case of manufacturing where the pressure of recession and import competition have caused labor negotiations to focus on job security more than real wage gains, despite rising productivity. But even if 1986 compensation was raised by $4 \%$ (to adjust for the

18. I wish to thank Jim Klumpner of the JEC staff for Figure 6 and the discussion of the points of this paragraph.

19. Prior to 1982 the CPI-X1 was similar to the standard CPI (Consumer Price Index) except that it measured housing costs using rental equivalents rather than house prices. Beginning in 1982, the CPI-X1 became the "official" CPI. A different choice for adjusting compensation would not have produced such dramatic results. For example, between 1980 and 1986, the implicit GNP deflator rose by $37.3 \%$ while the Personal Consumption Expenditure component of the GNP deflator rose by $38 \%$. 
decline in GNP share) it would remove only a small portion the slowdown in earnings growth shown in Table 1. Ultimately, that slowdown must be explained by the slow growth of output per worker.

The pre-1973 growth of real earnings (and the corresponding growth of family incomes) played important roles in national life-for example, the sense that each generation would live better than its parents. Consider a young man who, at age 18, left his parents' home. As he left, he observed what his father's paycheck would buy and he kept the observation as a personal yardstick. In the 1950s and 1960s, the young man would have measured up quickly: by the time he was 30 , his real earnings would have been 15-20\% greater than his father's earnings had been 12 years earlier. ${ }^{20}$ The young man would have known early in his career that he could live at least as well as he had seen his parents live. (I discuss a related issue-the expansion of the middle class-in Section 5.)

The growth of real wages also helped to cushion the loss of "good jobs" that occurs even in periods of strong economic growth (Schumpeter, 1942, Chapter 8). The loss of a good job often results in taking a different job at lower pay (e.g., Horvath 1987). When real wages are growing throughout the economy, a worker can imagine regaining his old real wage in a few years and relative earnings declines do not lead to absolute earnings declines, at least in the long run. But when real wages are stagnant, absolute earnings declines (and the permanent loss of "good jobs") are far more likely. I look at the issue of good and bad jobs in greater detail in the next section.

\section{A Loss of Good Jobs?}

In 1984, the Joint Economic Committee of the U.S. Congress published "The Great American Job Machine," a paper authored by Barry Bluestone and Bennett Harrison (1986). The authors argued that while the economic expansion of 1982-84 had created a large number of new jobs, most were in what they defined as the "low wage" category. By their calculations, $58 \%$ of the net new jobs created between 1979 and 1984 paid less than $\$ 7,012$ per year (or $\$ 7,712$ in 1987 dollars). "The Great American Job Machine" was an influential paper both for the media attention it received and the way it shaped the debate over the economy's performance. Even many of Bluestone and Harrison's critics

20. Richard Easterlin (1980) develops similar examples for point-in-time comparisons. As Table 1 suggests, the father's income would have grown over these 12 years as well. 
to address the "good jobs" argument in Bluestone and Harrison's terms. $^{21}$

In particular, both Bluestone-Harrison and many of their critics used shifts in the distribution of real annual earnings to draw inferences about changes in the relative number of jobs with high hourly wages ("good jobs"). ${ }^{22}$ This is, as I noted in Section 1, a big leap because shifts in the distribution of real annual earnings can arise from a number of different factors.

One factor is a changing composition of the work force. At a point in time, wage rates tend to rise with experience (holding education constant) and with education (holding experience constant). It follows that a shift in the age/education composition of the work force can shift the distribution of annual earnings even if workers of a given age and education earn precisely what their counterparts earned in previous years.

A second factor is hours worked. In popular debate, "good jobs" refer to jobs that pay high hourly wages but the good jobs debate has been based on the distribution of annual earnings data. One example of the problems this can cause is the upward trend in working women's annual hours of work: a trend that could shift the distribution of women's annual earnings upward even though wage rates had not changed.

Finally, macroeconomic events-unanticipated inflation, changes in the level of productivity, etc. - can shift the distribution of real annual earnings distribution even when the number of steel workers, fast food clerks, professors, etc. remains constant.

The annual earnings distributions of men and women shown in Section 1 (Figures 2 and 3) were potentially influenced by all of these factors. $^{23}$ To begin to disentangle these effects, Table 2 focuses on 1973, 1979 , and 1986 mean annual earnings and estimated hourly wages of 2555-year-old year-round full-time workers subdivided by sex, age, and selected educational levels (1987 dollars, PCE adjusted). Earnings distri-

21. A sample of critical commentary includes Kosters and Ross (1988), Samuelson (1987), Brookes (1987), and the Council of Economic Advisers (1988) while Norwood (1987) is slightly more agnostic. Another article relevant to the debate is Rosenthal (1985).

22. Here and elsewhere in this paper, I use the term "wages" to refer to the hourly rate of compensation of any employee, including those whose pay is contracted on a weekly, monthly, or annual basis.

23. The distributions in Figures 2 and 3 differ in several respects from the distributions used by the authors in the "good jobs" debate. Where Figures 2 and 3 focus on 25-55year-old workers, those articles often focused on all workers age 16 and above. Where Figures 2 and 3 present the data in \$10,000 increments, most articles in the debate use two real dollar cut-offs to divide annual earnings into a "low-medium-high" classification. In practice, different authors have chosen different cut-offs and this has further confused the issue. 
Table 2 CHANGES IN MEAN INDIVIDUAL EARNINGS FOR MEN AND WOMEN WHO WORK FULL-TIME, BY AGE AND SELECTED EDUCATIONAL LEVEL: 1973, 1979, AND 1986 (1987 DOLLARS)

\begin{tabular}{|c|c|c|c|c|c|c|}
\hline & & $n$ Earning & & & ent Change & \\
\hline & (Perce & $\begin{array}{l}\text { Earning } \\
\text { or Less) }\end{array}$ & 0,000 & Annual & Earnings & Wages \\
\hline & 1973 & 1979 & 1986 & 1979 & 1986 & 1986 \\
\hline Men, 25-34 & & & & & & \\
\hline 4 yrs. H.S. & $\begin{array}{l}\$ 26,364 \\
(27.0 \%)\end{array}$ & $\begin{array}{l}\$ 24,701 \\
(36.0 \%)\end{array}$ & $\begin{array}{l}\$ 22,226 \\
(47.5 \%)\end{array}$ & $-6 \%$ & $-16 \%$ & $-17 \%$ \\
\hline 4 yrs. col. & $\begin{array}{l}\$ 32,036 \\
(14.7 \%)\end{array}$ & $\begin{array}{l}\$ 29,062 \\
(23.6 \%)\end{array}$ & $\begin{array}{l}\$ 31,745 \\
(22.6 \%)\end{array}$ & $-9 \%$ & $-1 \%$ & $-3 \%$ \\
\hline Men, 35-44 & & & & & & \\
\hline 4 yrs. H.S. & $\begin{array}{l}\$ 29,736 \\
(19.0 \%)\end{array}$ & $\begin{array}{l}\$ 28,992 \\
(24.5 \%)\end{array}$ & $\begin{array}{l}\$ 27,738 \\
(28.4 \%)\end{array}$ & $-3 \%$ & $-7 \%$ & $-7 \%$ \\
\hline 4 yrs. col. & $\begin{array}{c}\$ 43,331 \\
(9.3 \%)\end{array}$ & $\begin{array}{l}\$ 40,555 \\
(11.8 \%)\end{array}$ & $\begin{array}{l}\$ 40,194 \\
(13.2 \%)\end{array}$ & $-6 \%$ & $-7 \%$ & $-9 \%$ \\
\hline Men, 45-54 & & & & & & \\
\hline 4 yrs. H.S. & $\begin{array}{l}\$ 30,621 \\
(19.8 \%)\end{array}$ & $\begin{array}{l}\$ 29,773 \\
(23.5 \%)\end{array}$ & $\begin{array}{l}\$ 29,520 \\
(24.2 \%)\end{array}$ & $-3 \%$ & $-4 \%$ & $-8 \%$ \\
\hline 4 yrs. col. & $\begin{array}{c}\$ 45,757 \\
(8.4 \%)\end{array}$ & $\begin{array}{l}\$ 43,565 \\
(10.9 \%)\end{array}$ & $\begin{array}{l}\$ 45,973 \\
(11.5 \%)\end{array}$ & $-5 \%$ & - & $+1 \%$ \\
\hline Women, 25-34 & & & & & & \\
\hline 4 yrs. H.S. & $\begin{array}{l}\$ 15,157 \\
(83.1 \%)\end{array}$ & $\begin{array}{l}\$ 15,516 \\
(81.0 \%)\end{array}$ & $\begin{array}{l}\$ 15,700 \\
(77.0 \%)\end{array}$ & $+2 \%$ & $+4 \%$ & $-8 \%$ \\
\hline 4 yrs. col. & $\begin{array}{l}\$ 20,733 \\
(47.9 \%)\end{array}$ & $\begin{array}{l}\$ 20,116 \\
(57.8 \%)\end{array}$ & $\begin{array}{l}\$ 23,333 \\
(43.7 \%)\end{array}$ & $-3 \%$ & $+13 \%$ & $+5 \%$ \\
\hline Women, 35-44 & & & & & & \\
\hline 4 yrs. H.S. & $\begin{array}{l}\$ 16,006 \\
(77.4 \%)\end{array}$ & $\begin{array}{l}\$ 15,963 \\
(78.7 \%)\end{array}$ & $\begin{array}{l}\$ 17,373 \\
(69.3 \%)\end{array}$ & - & $+9 \%$ & $+1 \%$ \\
\hline 4 yrs. col. & $\begin{array}{l}\$ 23,283 \\
(41.1 \%)\end{array}$ & $\begin{array}{l}\$ 21,391 \\
(51.4 \%)\end{array}$ & $\begin{array}{l}\$ 26,214 \\
(34.5 \%)\end{array}$ & $-8 \%$ & $+13 \%$ & $+5 \%$ \\
\hline Women, 45-54 & & & & & & \\
\hline 4 yrs. H.S. & $\begin{array}{l}\$ 16,406 \\
(77.3 \%)\end{array}$ & $\begin{array}{l}\$ 16,456 \\
(76.6 \%)\end{array}$ & $\begin{array}{l}\$ 17,400 \\
(67.2 \%)\end{array}$ & - & $+6 \%$ & $+3 \%$ \\
\hline 4 yrs. col. & $\begin{array}{l}\$ 23,075 \\
(39.3 \%)\end{array}$ & $\begin{array}{l}\$ 21,549 \\
(51.4 \%)\end{array}$ & $\begin{array}{l}\$ 25,001 \\
(30.8 \%)\end{array}$ & $-7 \%$ & $+8 \%$ & $+2 \%$ \\
\hline
\end{tabular}

Source: Author's tabulations of CPS micro data files. 
butions are typically skewed upward and so each mean is accompanied by the proportion of the sample who earn less than $\$ 20,000 .^{24}$ From 1973 through 1979, the data exhibit the slow earnings growth described in Section 2. Relationships among the relative earnings of different groups also remained stable. From 1979 through 1986, the average earnings level in the work force continues to show little growth but relative earnings begin to diverge sharply around the average.

The post-1979 dispersion in relative earnings contains three general elements. First, women's earnings, while lower than men's earnings, grew faster than men's earnings. For example, among year-round fulltime workers, ages 25-34, with four years of college, women's annual earnings increased by $13 \%$ while men's annual earnings declined by $1 \%$. A similar pattern holds among women and men of most other age and educational levels: women's earnings increased while men's declined.

The second pattern involved workers' education. Among workers of a given sex and age, the earnings of the less educated workers usually showed the slowest gains (or the biggest declines). For example, among 35-44-year-old women who worked year-round and full-time, the earnings of women with four years of college grew by $13 \%$ over the period while the earnings of women with four years of high school grew by $4 \% .^{25}$

Finally, among all year-round workers of the same sex, the earnings of young, less educated workers grew less (or declined more) than the earnings of all other groups.

A more detailed look at the data shows that (estimated) hourly wages per se usually grew more slowly over the period than full-time annual earnings. As noted above, the CPS defines a full-time worker as someone who works 35 hours or more per week, a definition which still permits variation in annual hours worked over time. Women classified as year-round full-time workers averaged 36.8 hours of work per week in 1973 but 41.8 hours of work per week in 1986. Similarly, male full-time workers averaged 43.1 hours of work per week in 1973 and 45.3 hours of work per week in 1986. The last column of Table 2 adjusts mean changes in year-round full-time annual earnings for mean changes in hours worked to approximate changes in hourly wages. ${ }^{26}$ The resulting esti-

24. A more appropriate statistic for Table 2 would be median earnings but the computation of medians was too cumbersome for this paper.

25 . For clarity, the Table 2 is restricted to persons with exactly 12 or 16 years of education. Tabulations not published here indicate a generally monotonic relationship between earnings changes and education within each age-sex group.

26. The CPS does not report an individual's annual hours of work. Rather it reports the individual's hours of work in a "normal week" and the number of weeks worked per year (where full-time workers must report working at least 50 weeks per year). In 1986, 
mates of wage changes reproduce the three patterns noted above but at lower absolute rates of growth.

The gradual convergence of men's and women's earnings has been examined by a number of authors including Smith and Ward (1984) and Fuchs (1988). The standard demonstration of the convergence is based on the ratio of published median incomes of all women to all men who work year-around and full-time, a ratio which has grown from .57 in 1973 to .60 in 1979 to .65 in 1986 (U.S. Bureau of the Census 1987b). Because women who work year-round and full-time have increased their average hours worked, the standard demonstration is overstated. But the data in Table 2 demonstrate convergence even when hours are controlled.

The growing earnings gap between more and less educated workers has been less studied and is a reversal of past developments. In 1976, Richard Freeman published The Overeducated American, a book which highlighted the falling rate of return to a college diploma. In Freeman's description, America had reached a state of over-education in which:

... the economic rewards to college education are markedly lower than has historically been the case and/or in which additional investment in college training will drive down those rewards - a society in which education has become, like investments in other mature industries or activities a marginal rather than highly profitable endeavor. ( $p p .4-5)$.

Published U.S. Census data supported Freeman's view. Consider the behavior over time of the following ratio:

Median Income of 25-34-year-old men with 4 years of college

Median Income of 25-34-year-old men with 4 years of H.S. ${ }^{27}$

Throughout the 1950s, the ratio stood at about 1.3. By the end of the 1960 s the increasing number of college graduates had caused the ratio to fall to 1.25 . And by 1973-roughly the time Freeman was writing-it had fallen to 1.15 .

both numbers were reported as continuous variables. In 1973, the weeks worked variable was reported in classes with the top class being $50-52$ weeks per year. For this reason, changes in annual hours worked were estimated from changes in hours normally worked per week, calculated separately for each age-education-sex group of year-round full-time workers.

27. We use income statistics in this comparison rather than earnings per se because the Census did not publish separate earnings statistics in the 1950s and 1960s. 
The ratio remained between 1.15 and 1.2 for the rest of the 1970s. But then, as we have seen, the ground began to shift, most clearly under younger men (Table 2). Among 25-34-year-old men, the ratio grew to 1.30 in 1980 (a recession year) and kept increasing to 1.5 in $1986 .{ }^{28}$

Together, the data in Tables 1 and 2 begin to suggest a two-part story of post-1973 earnings changes. The first part is the combination of oilprice shocks and slow productivity growth which, together, slowed the rate of real wage growth for all workers. The second part is a set of shifts in the demand and supply of different kinds of labor which caused some workers' earnings to grow faster than the underlying trend and other workers' wages to grow more slowly. What remains to be determined is the relative importance of supply shifts and demand shifts in this story.

I begin to look at this question in Table 3 which extends Table 2 to look at the 1973 and 1986 mean earnings of all men and women, ages 25-55, who worked at least one hour for pay during the year (the basis for Figures 2 and 3). For purposes of comparison, Table 3 reproduces from Table 2 the percentage change in earnings for the subset of workers who worked year-round and full-time. Earnings patterns for all workers replicate earnings patterns for year-round full-time workers with slightly larger amplitudes; this suggests that groups who saw wage gains also saw gains in average hours worked, while groups that saw wage declines saw declining average hours as well. The fact that wages and hours were moving in the same direction suggests that relative wage movements were primarily driven by shifts in demand. ${ }^{29}$

Table 4 addresses the issue of supply and demand more directly by comparing changes in a group's mean annual earnings with changes in the group's size. These data also point to the importance of demand shifts in relative earnings movements. Among men or women of a given age, the number of college educated workers grew more quickly than the number of high school educated workers but high school workers' earnings grew more slowly. Similarly, among workers of a given age and education, the number of working women grew more rapidly than the number of working men but women's mean earnings increased while men's mean earnings declined or, in a few cases, remained constant.

28. This fact seems to have been discovered more or less independently by Levy and Michel (1987), Sum and Fogg (1987), Murphy and Welch (1988), and Freeman (personal communication).

29. Ideally, one would verify this fact by directly tabulating annual hours worked. As noted earlier, however, the 1973 Current Population Survey only contains data on hours normally worked per week (a continuous variable) and weeks worked per year (a classified variable). Among people who work part-year, weeks worked is coded in broad classes-e.g., 27-39 weeks-which mean that annual hours of work can be estimated only with great imprecision. 
Table 3 MEAN EARNINGS OF ALL MEN AND WOMEN WITH $\$ 1$ OR MORE OF EARNINGS, 1973 AND 1986, (1987 DOLLARS)

\begin{tabular}{|c|c|c|c|c|}
\hline & \multicolumn{2}{|c|}{$\begin{array}{l}\text { Mean Annual } \\
\text { Earnings In: } \\
\text { (Percent Earning } \\
\$ 20,000 \text { or Less) }\end{array}$} & \multirow{2}{*}{$\begin{array}{l}\text { Percent } \\
\text { Change in } \\
\text { Earnings } \\
\text { for All } \\
\text { Workers }\end{array}$} & \multirow{2}{*}{$\begin{array}{c}\text { (Percent Change } \\
\text { in Earnings for } \\
\text { Subset of } \\
\text { Year-Round } \\
\text { Full-Time Workers) }\end{array}$} \\
\hline & 1973 & 1986 & & \\
\hline \multicolumn{5}{|l|}{ Men, 25-34 } \\
\hline 4 yrs. H.S. & $\begin{array}{l}\$ 24,267 \\
(35.7 \%)\end{array}$ & $\begin{array}{l}\$ 19,410 \\
(60.2 \%)\end{array}$ & $-20 \%$ & $-16 \%$ \\
\hline 4 yrs. col. & $\begin{array}{l}\$ 28,339 \\
(27.7 \%)\end{array}$ & $\begin{array}{l}\$ 29,170 \\
(32.5 \%)\end{array}$ & $+3 \%$ & $-1 \%$ \\
\hline \multicolumn{5}{|l|}{ Men, 35-44 } \\
\hline 4 yrs. H.S. & $\begin{array}{l}\$ 27,946 \\
(25.5 \%)\end{array}$ & $\begin{array}{l}\$ 25,103 \\
(41.8 \%)\end{array}$ & $-11 \%$ & $-7 \%$ \\
\hline 4 yrs. col. & $\begin{array}{l}\$ 41,926 \\
(12.8 \%)\end{array}$ & $\begin{array}{l}\$ 38,374 \\
(20.1 \%)\end{array}$ & $-8 \%$ & $-7 \%$ \\
\hline \multicolumn{5}{|l|}{ Men, 45-54 } \\
\hline 4 yrs. H.S. & $\begin{array}{l}\$ 28,102 \\
(28.5 \%)\end{array}$ & $\begin{array}{l}\$ 27,133 \\
(37.9 \%)\end{array}$ & $-3 \%$ & $-4 \%$ \\
\hline 4 yrs. col. & $\begin{array}{l}\$ 42,988 \\
(14.7 \%)\end{array}$ & $\begin{array}{l}\$ 43,803 \\
(18.4 \%)\end{array}$ & $+2 \%$ & - \\
\hline \multicolumn{5}{|l|}{ Women, 25-34 } \\
\hline 4 yrs. H.S. & $\begin{array}{r}\$ 9,870 \\
(94.9 \%)\end{array}$ & $\begin{array}{l}\$ 11,133 \\
(89.9 \%)\end{array}$ & $+13 \%$ & +4 \\
\hline 4 yrs. col. & $\begin{array}{l}\$ 14,876 \\
(78.1 \%)\end{array}$ & $\begin{array}{l}\$ 18,850 \\
(64.1 \%)\end{array}$ & $+27 \%$ & $+13 \%$ \\
\hline \multicolumn{5}{|l|}{ Women, 35-44 } \\
\hline 4 yrs. H.S. & $\begin{array}{l}\$ 10,926 \\
(92.2 \%)\end{array}$ & $\begin{array}{l}\$ 12,440 \\
(85.8 \%)\end{array}$ & $+14 \%$ & $+9 \%$ \\
\hline 4 yrs. col. & $\begin{array}{l}\$ 14,878 \\
(80.1 \%)\end{array}$ & $\begin{array}{l}\$ 19,837 \\
(62.3 \%)\end{array}$ & $+33 \%$ & $+27 \%$ \\
\hline $\begin{array}{l}\text { Women, } 45-54 \\
4 \text { yrs. H.S. }\end{array}$ & $\begin{array}{l}\$ 12,233 \\
(91.1 \%)\end{array}$ & $\begin{array}{l}\$ 13,220 \\
(85.1 \%)\end{array}$ & $+8 \%$ & $+6 \%$ \\
\hline 4 yrs. col. & $\begin{array}{l}\$ 18,835 \\
(72.0 \%)\end{array}$ & $\begin{array}{l}\$ 19,753 \\
(59.5 \%)\end{array}$ & $+5 \%$ & $+3 \%$ \\
\hline
\end{tabular}

Source: Author's Tabulations of CPS micro data files. 
In sum, demand shifts do not explain absolute earnings gains and losses-oil price shocks and the productivity slowdown are the principal cuprits here. But demand shifts help to explain relative earnings gains and losses-why some groups did better than the generally stagnant trend while others did worse.

A story of demand shifts begins by examining the distribution of workers across industries in the early 1970s where, for clarity, I have collapsed industries into four groups:

- Durable and Non-Durable Manufacturing

- Mining and Construction

- Agriculture

Table 4 CHANGES IN GROUP'S SIZE AND GROUP'S AVERAGE ANNUAL EARNINGS, FOR 25-55 YEAR-OLD MEN AND WOMEN WORKERS, 1973-1986

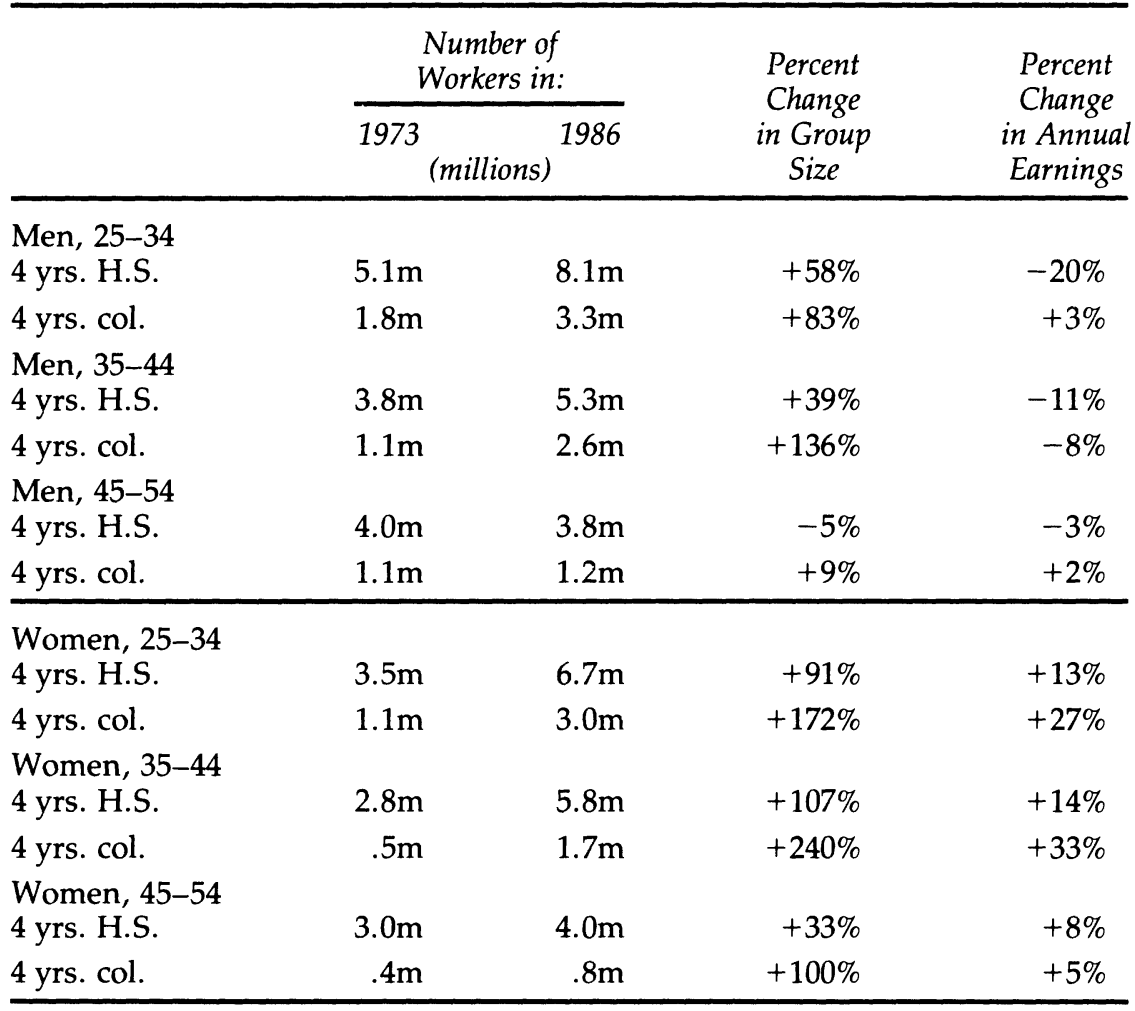

Source: Author's tabulations of March 1974 and March 1987 CPS micro data files. 
- The Service Sector including wholesale and retail trade, financeinsurance-and real estate, personal services, business and professional services, transportation-utilities-communication, and public administration

- Persons who were not employed during the year (for men only) ${ }^{30}$

Table 5 shows the 1973 distribution of men and women across these employment categories. In 1973, less educated men were concentrated in durable manufacturing and other goods producing industries while more educated men and women were concentrated in services. Among men with a high school education or less, about $45 \%$ were employed in durable manufacturing or other goods industries while about $40 \%$ were employed in the service sector. Among men with at least some college, about $60 \%$ were employed in the service sector. Among women, the proportion employed in the service sector ran from $54 \%$ (for women who had not graduated high school) to $97 \%$ (for women with more than four years of college).

At this point, it is useful to ask where the "good jobs" were in 1973: Which industries paid men ${ }^{31}$ relatively high annual earnings (holding observed characteristics constant). In recent years, it has become a clichè that good jobs are in manufacturing while the bad jobs are in services. While the clichè is stated in general terms, it clearly refers to good and bad jobs for less educated workers (or all today's pre-law and prefinance undergraduates are making a terrible mistake). But even if I restrict attention to less educated men, earnings patterns in the early 1970 s were slightly more complex than the clichè suggests.

Table 6 contains estimates of two-digit industry effects on the annual earnings of men with four years of high school and, for comparison, men with four years of college. ${ }^{32}$ The 1973 estimates for high school men show that annual earnings in Retail Sales were about $13 \%$ less than annual earnings in Durable Manufacturing, the kind of gap noted 20 years ago by Victor Fuchs (1968). But annual earnings were slightly higher in Transportation, Communications, and Utilities (with the high capital intensity described by Katz and Summers (1988)) and in Whole-

30. Later in this section, we will compare industrial distributions for women in 1973 and 1986. Women's labor force participation increased sharply during this period and this makes it hard to separate industrial shifts from increased labor supply. For this reason, we confine women's industrial distributions to working women.

31 . We restrict this discussion to men because women were already highly concentrated in the service sector (the sector of "bad jobs" in the popular debate).

32. Estimates come from separate regressions for each educational group, controlling for age and industry. Age-industry interactions for 23-34-year-old workers (i.e., entry level workers) proved insignificant. 


\section{Table 5 DISTRIBUTION OF MEN AND WOMEN ACROSS INDUSTRIAL SECTORS, 1973}

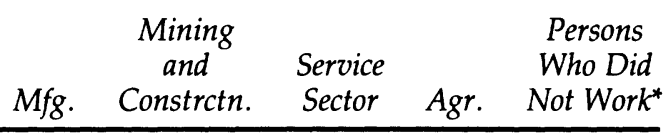

All Men, 25-55,

by education

$\begin{array}{llllll}\text { L.T. H.S. } & .32 & .16 & .35 & .07 & .10 \\ \text { H.S. Grad. } & .32 & .12 & .48 & .04 & .04 \\ 1-3 \text { yrs. col. } & .26 & .08 & .59 & .02 & .05 \\ 4 \text { yrs. col. } & .24 & .06 & .65 & .02 & .03 \\ 4+\text { yrs. col. } & .14 & .02 & .80 & .01 & .03\end{array}$

Women, 25-55,

by education

L.T. H.S.

H.S. Grad.

.35

.20

$1-3$ yrs. col.

4 yrs. col.

.12

.06

$4+$ yrs. col.

.02

\begin{tabular}{llll}
.01 & .54 & .09 & $\mathrm{n} / \mathrm{a}$ \\
.02 & .76 & .02 & $\mathrm{n} / \mathrm{a}$ \\
.01 & .86 & .01 & $\mathrm{n} / \mathrm{a}$ \\
.02 & .91 & .01 & $\mathrm{n} / \mathrm{a}$ \\
.01 & .97 & .00 & $\mathrm{n} / \mathrm{a}$ \\
\hline
\end{tabular}

*Data for women exclude persons who did not work during the year. See text for explanation. Source: Author's tabulations of the March 1974 CPS micro data files.

Table 6 EFFECTS OF INDUSTRY ON THE ANNUAL EARNINGS OF SELECTED 25-34-YEAR-OLD MEN (REFERENCE GROUP IS MEN IN NON-DURABLE MANUFACTURING)

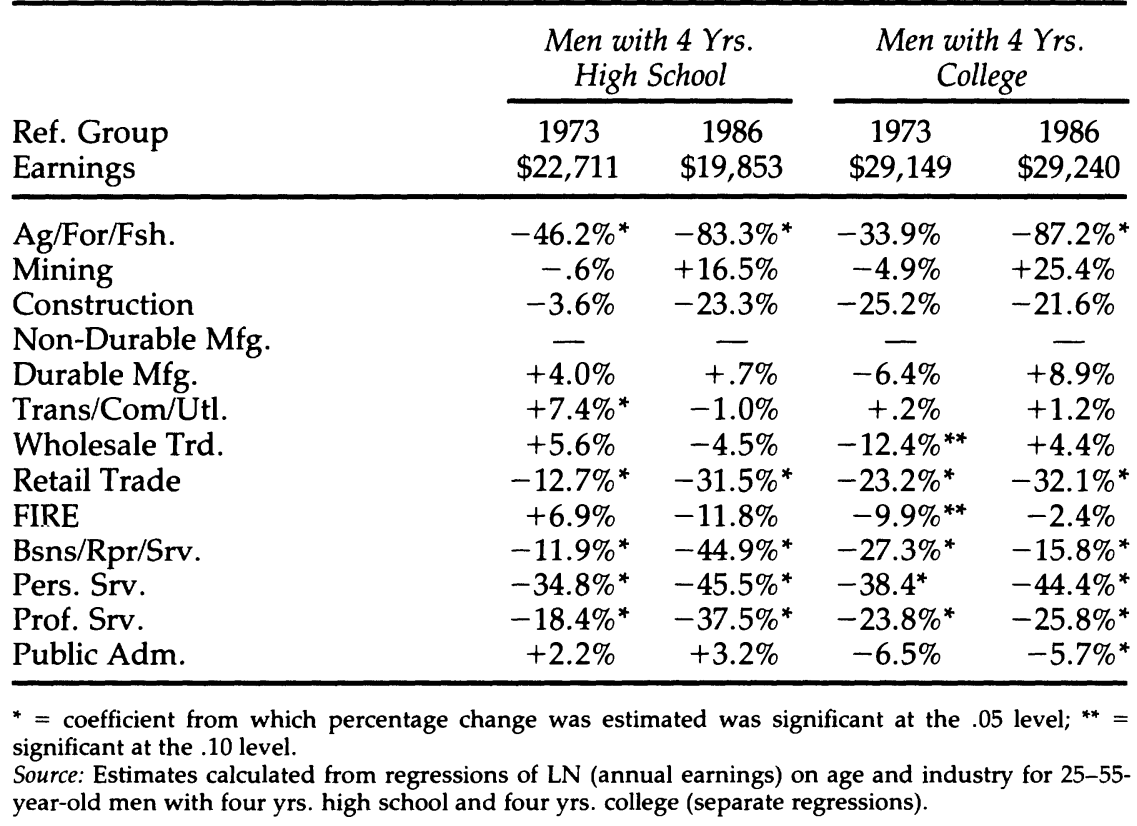


sale Trade. If anything, the 1973 earnings pattern for young men with four years of college fit the clichè slightly better.

The earnings patterns for less educated men point to the possibility of a disequilibrium in which at least some men were working in the service sector (outside Transportation, Communications, and Utilities) because vacancies in higher wage industries were not available. ${ }^{33}$

In the 13 years after 1973, vacancies in manufacturing, in particular did not grow appreciably. Manufacturing-particularly durable manufacturing-is sensitive to economic downturns. The years after 1973 saw two sharp downturns: $1973-75$ and 1980-82 (Lawrence 1982). Beyond this, the post 1982 recovery was accompanied by an overvalued high dollar which further undercut both foreign and domestic demand for U.S. manufactured goods. Between 1973 and 1979, employment on manufacturing payrolls increased by $5 \%$, much less than the growth in the male labor force. Between 1979 and 1986, employment on manufacturing payrolls declined by $10 \%$. (Council of Economic Advisers, 1989).

Table 7 compares the 1973, 1979, and 1986 industrial distributions of men and women. Among 25-34-year-olds with a high school education, the proportion in manufacturing fell sharply from .34 to .24 with most of the drop coming after 1979. Conversely, among 25-34-year-old men with four years of college, the proportion of college educated men in manufacturing held steady at .20. The comparison is noteworthy because the absolute number of college educated men in this age group grew faster than the number of high school educated men (Table 4). This suggests that less educated young men were losing manufacturing jobs not only because of the slow growth of manufacturing employment but because the composition of that employment was shifting toward more educated workers.

In theory, the shift of younger, less educated men out of goods production might have been a voluntary response to more attractive alternatives in other sectors. The 1986 pattern of high school men's earnings by industry in Table 6 suggests this was not the case: the earnings gap between manufacturing and service sector industries was sharper and more uniform in 1986 than it had been in 1973. More plausibly, the contraction of manufacturing employment placed young, less educated men in a position of excess supply. To a limited extent, service sector

33. One might postulate a similar disequilibrium among college educated men except that industry-specific training makes substitution across industries more problematic (e.g., moving from being a retail manager to being an engineer). 
industries acted as an absorbing buffer, but at the cost of a steep decline in service sector earnings, which led to the sharpened manufacturing/ services distinction noted above. ${ }^{34}$ More generally, the movement of younger, less educated men out of manufacturing did not represent more service sector employment so much as more young men out of the labor force. The earnings statistics in Tables 2 and 3 exclude men who do not work during the year but the existence of such men also points to their being in excess supply. The result was a sharp decline in the relative earnings of young, less educated men in all sectors (Table 6) including manufacturing. ${ }^{35}$

When compared to young, less educated men, other groups of workers were in relatively stronger positions. Older, less educated men had the benefit of job seniority while better educated men and most women were heavily concentrated in the service sector and so were relatively insulated from the problems of manufacturing. ${ }^{36}$ Better educated women, in particular, appear to have benefited from a moderate amount of occupational mobility (Bianchi and Spain 1986).

It follows that a resolution of the good jobs-bad jobs debate must make three points. The first point is the slow growth of earnings-a macroeconomic phenomenon-which affected earnings in all sectors. Today, a young man (or woman) with four years of college can accept what used to be called a good white collar job for $\$ 25,000$ and wonder whether he will ever be able to afford a house like the one in which he grew up. In this sense, weak productivity growth (and the income losses of oil price shocks) have limited the number of jobs with "middle class paychecks" and have helped create a wide audience for the good jobs-bad jobs debate.

The second poin: is the shift in demand away from young, less educated male workers. In 1973, $64 \%$ of male high school graduates, ages 25-34, earned more than $\$ 20,000$ per year (in 1987 dollars). By 1986, the corresponding proportion had declined to $40 \%$. Shifts in demand occur all the time, of course, but reduced demand in a context of general stagnation has much more serious implications. Elsewhere, I have estimated that today's 30-year-old male high school graduate will have trouble out-earning his high school educated father if labor productivity

34. Earnings in Transportation, Communications, and Utilities also dropped as a result of deregulation.

35. A recent paper by Blackburn, Bloom, and Freeman (1989) similarly concludes that the decline in the earnings of young, less educated men, is much more a function of wage declines within industries than shifts of employment across industry.

36. Though it appears from Tables 5 and 6 that young, less educated women faced some of the same pressure from manufacturing as young, less educated men. 
Table 7 DISTRIBUTION OF MEN AND WOMEN ACROSS INDUSTRIAL SECTORS, BY SELECTED AGE AND EDUCATION, 1973, 1979, AND 1986

\begin{tabular}{|c|c|c|c|c|c|}
\hline & $M f g$. & $\begin{array}{c}\text { Other } \\
\text { Goods } \\
\text { Industries }\end{array}$ & $\begin{array}{l}\text { Service } \\
\text { Sector }\end{array}$ & Agr. & $\begin{array}{c}\text { Persons } \\
\text { Who Did } \\
\text { Not Work }\end{array}$ \\
\hline $\begin{array}{l}\text { Men, } 25 \\
\text { H.S. Gr }\end{array}$ & & & & & \\
\hline $\begin{array}{l}1973 \\
1979 \\
1986\end{array}$ & $\begin{array}{l}.34 \\
.32 \\
.24\end{array}$ & $\begin{array}{l}.14 \\
.14 \\
.17\end{array}$ & $\begin{array}{l}.46 \\
.44 \\
.48\end{array}$ & $\begin{array}{l}.03 \\
.03 \\
.04\end{array}$ & $\begin{array}{l}.03 \\
.06 \\
.07\end{array}$ \\
\hline $\begin{array}{c}4 \text { yrs. cc } \\
1973 \\
1979 \\
1986\end{array}$ & $\begin{array}{l}.20 \\
.20 \\
.20\end{array}$ & $\begin{array}{l}.06 \\
.07 \\
.06\end{array}$ & $\begin{array}{l}.68 \\
.66 \\
.70\end{array}$ & $\begin{array}{l}.02 \\
.03 \\
.02\end{array}$ & $\begin{array}{l}.04 \\
.04 \\
.02\end{array}$ \\
\hline $\begin{array}{c}\text { Men, } 35 \\
\text { H.S. Gr } \\
1973 \\
1979 \\
1986\end{array}$ & $\begin{array}{l}.32 \\
.31 \\
.27\end{array}$ & $\begin{array}{l}.12 \\
.15 \\
.14\end{array}$ & $\begin{array}{l}.49 \\
.46 \\
.48\end{array}$ & $\begin{array}{l}.04 \\
.04 \\
.03\end{array}$ & $\begin{array}{l}.03 \\
.05 \\
.08\end{array}$ \\
\hline $\begin{array}{c}4 \text { yrs. c } \\
1973 \\
1979 \\
1986\end{array}$ & $\begin{array}{l}.28 \\
.22 \\
.23\end{array}$ & $\begin{array}{l}.05 \\
.06 \\
.06\end{array}$ & $\begin{array}{l}.64 \\
.66 \\
.67\end{array}$ & $\begin{array}{l}.02 \\
.02 \\
.02\end{array}$ & $\begin{array}{l}.01 \\
.03 \\
.02\end{array}$ \\
\hline $\begin{array}{l}\text { Men, } 4 \\
\text { H.S. Gr }\end{array}$ & & & & & \\
\hline $\begin{array}{l}1973 \\
1979 \\
1986\end{array}$ & $\begin{array}{l}.29 \\
.28 \\
.28\end{array}$ & $\begin{array}{l}.10 \\
.13 \\
.13\end{array}$ & $\begin{array}{l}.50 \\
.48 \\
.48\end{array}$ & $\begin{array}{l}.05 \\
.04 \\
.04\end{array}$ & $\begin{array}{l}.06 \\
.06 \\
.07\end{array}$ \\
\hline $\begin{array}{c}4 \text { yrs. c } \\
1973 \\
1979 \\
1986\end{array}$ & $\begin{array}{l}.26 \\
.28 \\
.27\end{array}$ & $\begin{array}{l}.08 \\
.05 \\
.06\end{array}$ & $\begin{array}{l}.60 \\
.62 \\
.63\end{array}$ & $\begin{array}{l}.02 \\
.01 \\
.01\end{array}$ & $\begin{array}{l}.04 \\
.03 \\
.03\end{array}$ \\
\hline $\begin{array}{l}\text { Women } \\
\text { H.S. Gr }\end{array}$ & & & & & \\
\hline $\begin{array}{l}1973 \\
1979 \\
1986\end{array}$ & $\begin{array}{l}.23 \\
.21 \\
.17\end{array}$ & $\begin{array}{l}.02 \\
.02 \\
.01\end{array}$ & $\begin{array}{l}.72 \\
.76 \\
.80\end{array}$ & $\begin{array}{l}.03 \\
.01 \\
.01\end{array}$ & $\begin{array}{l}n / a \\
n / a \\
n / a\end{array}$ \\
\hline $\begin{array}{c}4 \text { yrs. c } \\
1973 \\
1979 \\
1986\end{array}$ & $\begin{array}{l}.05 \\
.09 \\
.11\end{array}$ & $\begin{array}{l}.01 \\
.01 \\
.02\end{array}$ & $\begin{array}{l}.93 \\
.90 \\
.86\end{array}$ & $\begin{array}{l}.01 \\
.01 \\
.01\end{array}$ & $\begin{array}{l}n / a \\
n / a \\
n / a\end{array}$ \\
\hline $\begin{array}{l}\text { Women } \\
\text { H.S. Gr }\end{array}$ & & & & & \\
\hline $\begin{array}{l}1973 \\
1979 \\
1986\end{array}$ & $\begin{array}{l}.18 \\
.18 \\
.16\end{array}$ & $\begin{array}{l}.01 \\
.02 \\
.02\end{array}$ & $\begin{array}{l}.79 \\
.78 \\
.81\end{array}$ & $\begin{array}{l}.02 \\
.02 \\
.01\end{array}$ & $\begin{array}{l}\mathrm{n} / \mathrm{a} \\
\mathrm{n} / \mathrm{a} \\
\mathrm{n} / \mathrm{a}\end{array}$ \\
\hline
\end{tabular}


Table 7 DISTRIBUTION OF MEN AND WOMEN ACROSS INDUSTRIAL SECTORS, BY SELECTED AGE AND EDUCATION, 1973, 1979, AND 1986 (CONTINUED)

\begin{tabular}{|c|c|c|c|c|c|}
\hline & Mfg. & $\begin{array}{c}\text { Other } \\
\text { Goods } \\
\text { Industries }\end{array}$ & $\begin{array}{l}\text { Service } \\
\text { Sector }\end{array}$ & Agr. & $\begin{array}{c}\text { Persons } \\
\text { Who Did } \\
\text { Not Work }\end{array}$ \\
\hline \multicolumn{6}{|c|}{4 yrs. col. } \\
\hline 1973 & .03 & - & .96 & .01 & $\mathrm{n} / \mathrm{a}$ \\
\hline 1979 & .07 & .01 & .92 & .01 & $\mathrm{n} / \mathrm{a}$ \\
\hline 1986 & .07 & .01 & .91 & .01 & $\mathrm{n} / \mathrm{a}$ \\
\hline \multicolumn{6}{|c|}{$\begin{array}{l}\text { Women 45-55 } \\
\text { H.S Grad. }\end{array}$} \\
\hline H.S. Gr & & & & & \\
\hline 1973 & 19 & .01 & .77 & .03 & $\mathrm{n} / \mathrm{a}$ \\
\hline 1979 & .18 & .02 & .79 & .02 & $\mathrm{n} / \mathrm{a}$ \\
\hline 1986 & .17 & .01 & .79 & .03 & $\mathrm{n} / \mathrm{a}$ \\
\hline \multicolumn{6}{|c|}{4 yrs. col. } \\
\hline 1973 & .04 & .01 & .94 & .01 & $\mathrm{n} / \mathrm{a}$ \\
\hline 1979 & .05 & .02 & .92 & .02 & $\mathrm{n} / \mathrm{a}$ \\
\hline 1986 & .06 & - & .93 & .01 & $\mathrm{n} / \mathrm{a}$ \\
\hline
\end{tabular}

Note: Rows may not sum to 1.00 due to rounding.

Source: Author's Tabulations of the March 1974, March 1980, and March 1987 CPS micro data files. CPS public use sample.

continues to grow at recent rates (Levy 1988b), something that is quite new in the American experience. ${ }^{37}$

Finally, the good jobs-bad jobs debate is more a story about men (in particular, young, less educated men) than women. Women's earnings are systematically below those of men but the proportion of women earning more than $\$ 20,000$ per year rose from $16 \%$ in 1973 to 27 percent in 1986. A large part of this increase reflects increased hours of work but at least some part reflects rising real wages. Among younger women there is some evidence of growing inequality between more and less educated workers. But on the whole, women's position in the labor market improved moderately over this period both in absolute terms and relative to men.

\section{Income Per Worker and Income Per Capita}

In the long view of U.S. economic history, the period from the end of World War II through 1973 was unusual for its relative tranquility and its

37. In similar calculations, I estimate that today's 30-year-old male college educated worker will out-earn his college educated father but only by about 5 percent, much less than the 1950s and 1960s. 
sustained income growth. During this time, Americans experienced steadily rising living standards with the benefits described in Section 2: young people's certainty that they would live better than their parents, a "cushion" for shifting employment patterns, and so on. In this context, the post-1973 stagnation of worker's incomes might have come as an enormous shock to the country.

There was a shock, ${ }^{38}$ but it was smaller than one might have expected. One data series helps explain the reason. Income per capita, the most widely used measure of living standards, was growing strongly even though individual wage rates were not. The Census reports that between 1973 and 1986, the median income of all men who worked yearround and full-time declined from $\$ 27,490$ to $\$ 26,926(-2 \%)$ while the comparable figure for women rose from $\$ 15,533$ to $\$ 17,147(+10 \%)$. Over the same period, the Census measure of income per capita (i.e., Census defined income per man, woman and child) rose briskly from $\$ 9,926$ to $\$ 12,250$, $(+22 \%)$. As noted in Section 1, the Census measures pre-tax, money receipts (excluding capital gains) but the Department of Commerce measure of disposable income per capita, which corrects for taxes paid, capital gains, and noncash income, also rose by $21 \%$ over the period.

The divergent trends in income per worker and income per capita can be reconciled by noting the substantial increase in the proportion of the population who worked. In 1973, the civilian labor force represented $42 \%$ of the entire U.S. population. By 1986, the labor force represented $50 \%$ of the entire population. ${ }^{39}$ This increase in relative labor supply was the result of three factors: increases in women's labor force participation, the entrance of the largest baby-boom cohorts into the work force (as they entered their late teenage years and early 20s), and sustained low birth rates throughout the period.

In microcosm, these changes meant a sharp move away from "1950s families" with one paycheck and two or three children. 1980s families typically had two paychecks and one or two children. In the limit, a sharp rise in the median age at first marriage increased the number of persons who remained outside of families and who had only themselves

38. One can argue, for example, that one cause of the late-1970s taxpayer revolt was the tension between stagnant incomes and growing government expenditures. Idiosyncratic conditions in various states also played important roles (see Levy 1979).

39. See, for example, Council of Economic Advisers (1989), Tables B-31 and B-32. Note that the figures refer to the ratio of the labor force to the entire population rather than the population aged 16 and over which is used in the computation of labor force participation rates. 
to support. ${ }^{40}$ For the economy as a whole, the changes meant that income per capita (per man, woman, and child) could keep rising despite stagnant income per worker because a growing proportion of the population was at work. ${ }^{41}$

To what extent were smaller families and increased women's labor force participation endogenous responses to stagnant earnings? The answer is far from clear. We know that women's labor force participation had been increasing steadily since the 1950s (Bianchi and Spain 1986), and the baby boom which ended in 1964 (Butz and Ward 1979), both well before the onset of stagnation. At the same time, each trend is consistent with income growth that fails to satisfy consumption aspirations and both trends might have leveled off sooner in an environment of strong wage growth (Elster and Kamlet 1987). Self-reported explanations of behavior are, of course, treacherous because people often see themselves as behaving normally-e.g., having a normal number of children-even while the norms themselves are changing rapidly over time.

What is clear is that demographic shifts are not a mechanism for continued increases in living standards. Today, about two-thirds of young husband-wife couples begin married life with both partners working. At the same time, the birth rate has stopped falling while the median age of first marriage has stopped increasing. Together, these trends place limits on further increases in the proportion of the population at work and they underline what is simply common sense: Whatever their short run divergence, income per capita can ultimately grow no faster than income per worker. ${ }^{42}$

40. In 1970, the median age of first marriage was 21 for women and 23 for men. By 1986, the median age of first marriage had risen by about two years for each group. See U.S. Bureau of the Census, 1987a.

41. During this period, the U.S. also increased its living standards through foreign borrowing, but Census income statistics are not a good device for measuring this increase. As a rough approximation, foreign borrowing permitted the federal government to sharply reduce taxes and run budget deficits without forcing drastic reductions in the rate of gross investment. Because Census incomes statistics are measured on a pre-tax basis, they do not capture the increase in disposable income that comes from reduced taxes. For a discussion of foreign borrowing and living standards, see Litan, Lawrence, and Schultze (1988), Chapters 1 and 2.

42. The stagnation in real incomes has also been questioned on the grounds that we do a poor job of measuring the output of the service sector-particularly convenience aspects - and so understate the growth of output. Recent work by Martin N. Baily and Robert J. Gordon (1988) have examined this question in the context of the productivity slowdown. They find that the probable mismeasurement of output is relatively small. 


\section{The Family Income Distribution}

In casual discussion, inequality in the earnings distribution and inequality in the family income distribution are often treated interchangeably. The two distributions are related, a relationship I begin to explore in the next section, but the distributions also differ in many respects. Put briefly, family incomes depend on trends in individual earnings but they also depend on trends in the number of earners per family as well as trends in incomes from sources other than earnings (interest payments, private pensions, government transfer payments, etc.).

In the years since World War II, Census measures of the U.S. family income distribution have displayed two main characteristics: substantial absolute inequality, and general stability. By Census measures, 1969, a year of extremely tight labor markets, was the year of greatest family income inequality. In that year, however, the poorest quintile of families received $5.6 \%$ of all family income while the richest quintile received $40.6 \%$, a ratio of about $\$ 1.00$ to $\$ 7.25$. In 1986, the corresponding ratio was $\$ 1.00$ to $\$ 9.50$, but as shown in Table 8 , a family did not have to be millionaires to be in the top fifth of families.

The best international comparisons of income inequality suggest that U.S. family income inequality is high not only absolutely but also relative to inequality in other countries. For example Sawyer (1976) shows that the poorest quintile of U.S. households received $3.8 \%$ of pre-tax income in 1972, compared to $5.4 \%$ in Germany (1973), $7.6 \%$ in Japan (1969), 4.4\% in the United Kingdom, $4.3 \%$ in Canada (1969), and so on. ${ }^{43}$ More recent work by Coder, Rainwater, and Smeeding (1988), using data developed by the Luxembourg Income Study, shows that in the 1979-83 period, the level of disposable income inequality among U.S. families was highest among the ten industrialized countries in their sample (including Germany, the United Kingdom, and Canada). ${ }^{44}$

The relative stability of U.S. family income inequality is displayed in Table 8. Through 39 years, the income share going to the poorest quintile of families has varied between $4.6 \%$ and $5.6 \%$ while the income share of the top quintile has varied between $40.6 \%$ and $43.7 \%$.

The variations in Table 8 are larger than they seem. For example, the income share of the lowest quintile has varied in a range of $1 \%$. But this is a range of $1 \%$ of all family income for a group that received

43. Households include both families and other living units in which the inhabitants are not related. I have used Sawyer's pre-tax income figures to in order to be consistent with the Census pre-tax income figures used throughout this paper. Sawyer also calculates post-tax distributions and arrives at similar conclusions.

44. This ranking was invariant to three inequality measures: Atkinson's measure (with $e=$ $.5)$, the Gini coefficient, and Theil's inequality index. 
only about $5 \%$ of all family income to begin with. In 1986, for example, an income share of $5.6 \%$ rather than $4.6 \%$ would have raised mean income in the lowest quintile from $\$ 8,363$ to $\$ 10,181$ (in 1987 dollars), no small difference. But over 39 years the size of these swings is relatively moderate.

The stability of the family income distribution over almost four decades raises three quite different questions. First, is the stability real or is it an artifact of Census data definitions and procedures? Second, how is the stability consistent with popular perceptions that the middle class grew dramatically in the 1950s and 1960s (Gans 1967), but is now "in danger of vanishing" (Kuttner 1983; Thurow 1984). Finally, why did inequality remain constant in the face of two developments favoring equality: the declining proportion of families in low wage agriculture, and the improving relative incomes of elderly families. I briefly address each question in turn.

As I noted in Section 1, the Census defines income as pre-tax money receipts excluding capital gains. Moreover, to preserve confidentiality, other income sources are reported with top codes ("caps") that change only infrequently. In 1986, for example, both wages and salaries and selfemployment income were not reported in excess of $\$ 100,000$ for any individual. In the early and mid-1980s, capital gains realizations were high and top salaries in many professions were growing fast. There is little doubt that during this period, income coding limits and the nonreporting of capital gains combined to understate both the level and

\section{Table 8 SHAPE OF THE U.S. FAMILY INCOME DISTRIBUTION}

\begin{tabular}{ccccccc} 
A. Share of All Family Income Going to Each Fifth of Families \\
$\begin{array}{c}\text { 1st } \\
\text { fifth } \\
\text { (poorest) }\end{array}$ & $\begin{array}{c}\text { 2nd } \\
\text { fifth }\end{array}$ & $\begin{array}{c}\text { 3rd } \\
\text { fifth }\end{array}$ & $\begin{array}{c}4 \text { th } \\
\text { fifth }\end{array}$ & $\begin{array}{c}5 \text { th } \\
\text { fifth } \\
\text { (richest) }\end{array}$ & Total \\
\hline 1949 & $4.5 \%$ & $11.9 \%$ & $17.3 \%$ & $23.5 \%$ & $42.7 \%$ & $100 \%$ \\
1959 & $4.9 \%$ & $12.3 \%$ & $17.9 \%$ & $23.8 \%$ & $41.1 \%$ & $100 \%$ \\
1969 & $5.6 \%$ & $12.4 \%$ & $17.7 \%$ & $23.7 \%$ & $40.6 \%$ & $100 \%$ \\
1979 & $5.2 \%$ & $11.6 \%$ & $17.5 \%$ & $24.1 \%$ & $41.7 \%$ & $100 \%$ \\
1986 & $4.6 \%$ & $10.8 \%$ & $16.8 \%$ & $24.0 \%$ & $43.7 \%$ & $100 \%$
\end{tabular}

B. 1986 Income Upper Limits for Each Quintile (1987 dollars)

$\begin{array}{cccc}\begin{array}{c}\text { 1st } Q \text { Ends } \\ \text { at }\end{array} & \begin{array}{c}\text { 2nd Q Ends } \\ \text { at }\end{array} & \begin{array}{c}\text { 3rd Q Ends } \\ \text { at }\end{array} & \begin{array}{c}\text { 4th } Q \text { Ends } \\ \text { at }\end{array} \\ \$ 14,500 & \$ 25,082 & \$ 36,564 & \$ 52,597\end{array}$

Note: Percentages may not add up to 100 due to rounding.

Source: U.S. Bureau of the Census (1986b) 
growth of income inequality in Census reports. ${ }^{45}$ Joseph Pechman, for example, has compiled data from the U.S. Treasury's annual Statistics of Income series, which show that the share of gross income received by the top one-fifth of filing units (as distinct from families) rose from $43.1 \%$ in 1981 to $52.3 \%$ in 1986 , a far larger shift than is implied by Census statistics (personal communication). Pechman further estimates that 6.6 percentage points of this 9.2 percentage point gain in share accrued to the top $1 \%$ of filing units. A 1987 study by Richard Kasten and Frank Sammartino of the Congressional Budget Office arrives at similar, but less dramatic conclusions for households (as distinct from families) (Congressional Budget Office 1987). ${ }^{46}$ Both studies are consistent with recent explorations of CPS data by Gottschalk, Danziger, and Smolensky (1988) who conclude that even among husband-wife families under age 65 , property income is important only among the top $1 \%$ of the population while the biggest income gains for the rest of this group have come from wives' earnings. In sum, even if one acknowledges the different units of observation used by the Census, Pechman, and the $\mathrm{CBO}$, it is almost certain that Census conventions that exclude capital gains and cap reported incomes have caused understated recent trends in income inequality particularly in the upper ranges of the distribution.

At the same time, reasonable adjustments for this understatement still would leave the inequality figures in Table 8 too uniform to be consistent with a rapidly expanding middle class in the 1950s and 1960s and a middle class under pressure in the 1980s. The issue is further muddled because in 1986, the top quintile of the family income distribution began at $\$ 52,597$ (in 1987 dollars), an income which many families see as squarely in the middle class. The major answer to this paradox, I believe, is the income growth and stagnation described in Section 2. Between 1947 and 1986, median family income rose from $\$ 14,830$ to $\$ 28,890$ (36 percent per decade). This growth was accompanied by rapid increases in the proportions of families who owned their own homes, and who owned cars, washing machines, dryers, televisions, air conditioners, and so on. The middle class was growing not because incomes were becoming substantially more equal but because more families could af-

45. There is the more general problem of non-response and underreporting of incomes, problems that are not limited to upper income groups. See Levy (1988a) Appendix B, Lillard, Smith, and Welch (1986).

46. Distributional studies based on households can be influenced by such factors as the rising age of first marriage which increases the number of single person households in the sample. The issue has become confused because CBO uses the term "family" to include both families (in the Census definition) and persons who live alone or with other non-relatives. 
ford a middle class style of living as we had come to define it (Levy 1988a, Chapter 4). Between 1973 and 1986, median family income grew from $\$ 28,890$ to $\$ 30,670$ (5\% per decade) and it was this stagnation which helped prompt fears of a vanishing middle class. There is a second element to fears of a vanishing middle class involving changes in the kinds of families that occupy various portions of the distribution. I return to this point shortly.

The relative stability of inequality is also suprising when one considers post-World War II population trends. In the late 1940s, the bottom quintile of the family income distribution was dominated by two kinds of families: elderly families (many of whom still worked) and farm families who comprised about $11 \%$ of all families and who typically reported very low money incomes. ${ }^{47}$ Since that time, rapid gains in agricultural productivity have reduced the need for agricultural labor and the proportion of families in agriculture has declined from $11 \%$ to $2 \%$. At the same time, successive cohorts of elderly families have benefited from greater Social Security coverage, indexed Social Security payments (after 1971) and greater private pension coverage. ${ }^{48}$ As a result, incomes of elderly families over the last 15 years have grown more rapidly than the incomes of non-elderly families (Council of Economic Advisors 1985; see also Table 9 below). These events, cet. par., should have increased family income equality particularly after 1971 but, of course, that did not occur.

A partial explanation for the trend in inequality since 1971 is contained in Table 9. These data show that while the incomes of elderly families were rising, the number of families headed by single women was growing rapidly. Among families headed by someone under age 65 , the proportion headed by a single woman rose from about one in eight in the early 1970s to one in five today, where in both years, the median incomes of such families were well below the incomes of other families in the population. The result was a kind of "swap" in which elderly families were moving from the bottom of the income distribution to the lower middle while their "vacated places" at the bottom were taken by new female-headed families with children.

I noted above that Census data understate the recent increase in family income inequality. The data in Table 9 suggest that such increased inequality as the Census does report might be driven by changes in family structure: the growing number of families who are either headed

47. Money incomes obviously understate the relative well-being of many farm families but the purpose of this discussion is to examine trends in reported Census (i.e., money income) statistics.

48. Peter Diamond reminds me that the incomes of elderly families were further increased because Social Security was not only indexed but over-indexed for much of the 1970 s. 
by a single woman or have two earners. The suggestion, while plausible, is wrong. Recent calculations by Eugene Smolensky suggest that wives' earnings have exerted a moderating influence on increased household income inequality (personal communication). Growing numbers of families headed by single women are clearly important in increased family income inequality but the growing inequality of male earnings is important as well. I return to this point in the next section.

I also noted above that population shifts within the income distribution add to perceptions of a vanishing middle class. In particular, the swap of female-headed families for elderly families at the bottom of the distribution has led to a situation in which income inequality among families with children has increased substantially (Figure 7). We saw in Section 4 that part of the post-1973 increase in income per capita reflected low national birth rates. In this context, a growing number of families headed by women led to an even more rapid growth in the proportion of children in female-headed families: .10 of all children in 1973 to .20 of all children in 1986. The result has been to increase the proportion of children in families with income under $\$ 10,000$ (1987 dollars) from one in nine in the early 1970s to one in six today. The growing number of poor children is highly visible and newsworthy-as it should be. Specifically, poor children are more visible than the improved incomes of the elderly, and this leads to a perception that income inequality is rising faster than the Census statistics report.

The perception, moreover, may contain a kernel of truth. If middle class families no longer drop to the bottom of the income distribution

Table 9 FREQUENCY AND MEDIAN INCOME OF MAJOR FAMILY TYPES, 1973, 1986 (INCOMES IN 1987 DOLLARS)

\begin{tabular}{|c|c|c|c|c|}
\hline \multirow[b]{2}{*}{$\begin{array}{l}\text { Family } \\
\text { Type }\end{array}$} & \multicolumn{2}{|c|}{1973} & \multicolumn{2}{|c|}{1986} \\
\hline & $\begin{array}{l}\text { Percent of } \\
\text { All Families }\end{array}$ & $\begin{array}{l}\text { Median } \\
\text { Income }\end{array}$ & $\begin{array}{l}\text { Percent of } \\
\text { All Families }\end{array}$ & $\begin{array}{l}\text { Median } \\
\text { Income }\end{array}$ \\
\hline All & $100 \%$ & $\$ 29,890$ & $100 \%$ & $\$ 30,670$ \\
\hline Family Head $\geq$ Age $65^{*}$ & $14.3 \%$ & $\$ 15,956$ & $15.8 \%$ & $\$ 20,752$ \\
\hline $\begin{array}{l}\text { Hus.-Wife }<65 \text {, } \\
\text { Wife does not Work }\end{array}$ & $39.7 \%$ & $\$ 30,218$ & $24.5 \%$ & $\$ 29,787$ \\
\hline $\begin{array}{l}\text { Hus.-Wife }<65 \\
\text { Wife Works }\end{array}$ & $33.6 \%$ & $\$ 37,158$ & $42.3 \%$ & $\$ 38,750$ \\
\hline Female Fam. Head $<65$ & $10.3 \%$ & $\$ 13,424$ & $14.4 \%$ & $\$ 11,308$ \\
\hline All other families & $2.1 \%$ & - & $3.0 \%$ & - \\
\hline
\end{tabular}

*Includes both male and female headed families over age 65.

Source: Current Population Reports, various issues. Some medians interpolated from published data. 
upon retirement and if low income female-headed families remain female-headed families for long periods of time (Bane and Ellwood 1986), it may be that mobility within the income distribution has declined over the last 15 years - that a fairly stable distribution of current family incomes obscures a growing inequality of permanent family incomes. This is a topic for future research.

\section{Earnings Inequality and Income Inequality}

To this point, I have emphasized inequality that arises from betweengroup differences: mean differences in earnings between high school and college educated workers, mean income differences between femaleheaded families and two-earner families, and so on. In this section, I look again at changes in family income inequality from a somewhat broader perspective. I showed in Sections 1 and 3 that earnings of prime age men have also become less equal over 1973-86 and we can reasonably ask to what extent this individual earnings inequality-a growing within-group difference-was translated into family income inequality. In this section, I present some illustrative, incomplete calculations on this question.

I begin by reviewing one version of the steps that link male earnings to family income. For clarity, I focus on men ages 25-34.

Figure 7 DISTRIBUTION OF CHILDREN BY FAMILY INCOME 1973, 1986

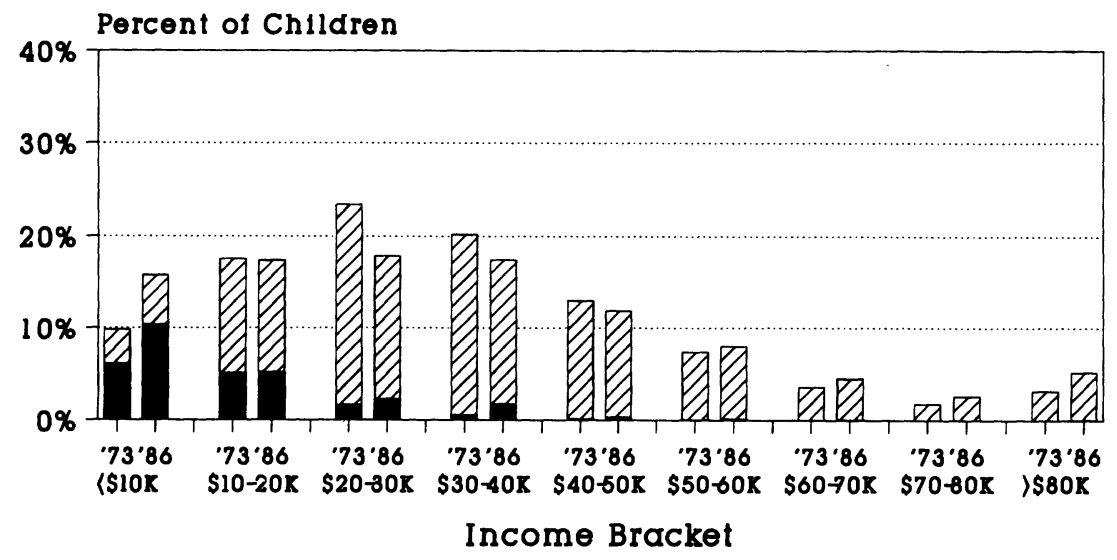

In Female-Head Fams. VIA All Other Children 
The process begins with the distribution of earnings of all men, ages 2534 , including men who have no earnings whatsoever. ${ }^{49}$

The next step is the move from the distribution of individual earnings to the distribution of individual incomes incluaing unemployment compensation, rents, dividends, and other income sources as reported by the Census.

The third step is the move from the distribution of individual incomes of all 25-34 men to the distribution of individual incomes of 25-34-yearold husbands.

The final step is the move from the individual incomes of all 25-34-yearold husbands to the family incomes of all 25-34-year-old husbands.

While earnings inequality among 25-34-year-old men has increased over time, the last two steps of the sequence have the potential of muting this inequality. Andrew Sum, among other authors, has shown that the individual incomes of married men are higher, on average, than the individual incomes of unmarried men with similar characteristics (Sum's work appears in Children's Defense Fund 1988).$^{50}$ It follows that moving from the individual incomes of all men to the individual incomes of married men (step 3 ) should both raise mean income and lower relative income inequality. ${ }^{51}$

In a similar fashion, I have shown, as have a number of other authors, that wives' earnings increase the relative equality of income of husbandwife families (Levy 1988, Chapter 8).$^{52}$ It follows that moving from husbands' individual incomes to the total of their families (step 4) should produce a distribution with a higher mean and lower relative inequality.

The issue, however, is not just the direction of these effects but the magnitudes of the effects: to what extent were the effects able to reduce

49. Men without earnings were excluded from Figure 2 and Tables 2 and 3 because my focus there was on the changing nature of employment. Men without earnings are included here because they are potential husbands who may appear in the family income distribution.

50. A priori, these earnings differences could correspond to either unmeasured differences in ability or the change in outlook brought about by the responsibilities of marriage. Attempts to determine the relative importance of these two factors have been generally unsuccessful.

51. By relative income inequality, I mean the coefficient of variation, the Gini index, Atkinson's index, etc. Absolute inequality-e.g., the variance of income-may well increase since husbands' incomes are higher, on average, than the incomes of all men.

52. This equality comes from two sources. First, wives' labor force participation falls as husbands' earnings rise (though this is becoming less true over time). Second, variations in working wives' earnings is less than the variation in husbands' earnings. The joint result is that the wives' percentage contribution to family income declines as husbands' earnings rise. 
the amount of individual earnings inequality that was passed through to the family income distribution.

Some rough calculations on this point appear in Table 10 which track the four steps described above for 25-34-year-old men with four years of high school, 25-34-year-old men with four years of college, and all 2534-year-old men (including Ph.D.'s, high school dropouts, etc.).

The results in the Table 10 support two general conclusions. First, as we move from individual earnings to family income, the processes described above reduce the coefficient of variation (c.o.v.) by a total of about $20 \%$ (e.g., . 518 versus .429 for 25-34-year-old high school men in 1974), a result that is consistent across all groups in the table. Second, the magnitudes of these percentage reductions were similar in 1974 and 1986 and so the increased earnings inequality of the period reappeared largely intact in the family income distribution. For all 25-34-year-old men, the c.o.v. for individual earnings rose from .603 in 1973 to .736 in $1986(+22 \%)$ while the c.o.v. for family income rose from .476 to .594 $(+.25 \%)$. Thus increased earnings inequality among men did have an impact on increased family income inequality.

The stable proportional reductions in inequality are surprising given the way in which marital patterns changed over the period. The rising age of first marriage (noted in Section 4) and related developments sharply reduced the proportion of 25-34-year-old men who were husbands. A priori, marriage might have increasingly acted to screen low income men out of the family income distribution. In practice, declining marriage rates were uniform across educational groups and the screening did not occur. Among 25-34-year-old husbands with a high school diploma, mean individual income fell from $\$ 26,262$ in 1973 to $\$ 21,752$ $(-17 \%)$. Among 25-34-year-old husbands with four years of college, mean individual income rose slightly over the period. In both cases, the changes in mean husbands' incomes parallel the changes in mean earnings for all men of similar characteristics (married or not). Thus among families headed by 25-34-year-old high school graduates, increased wives' earnings were needed to maintain 1986 family income at its 1973 level. Among families headed by $25-34$-year-old college graduates, increased wives' earnings caused family income to rise by about $14 \%$ over the period.

It should be noted that the calculations in Table 10 are only one of two mechanisms in which male earnings trends may have influenced family income inequality. The other mechanism is the postulated relationship between low men's earnings and the formation of female-headed families per se. A chief proponent of this view is William Julius Wilson who 


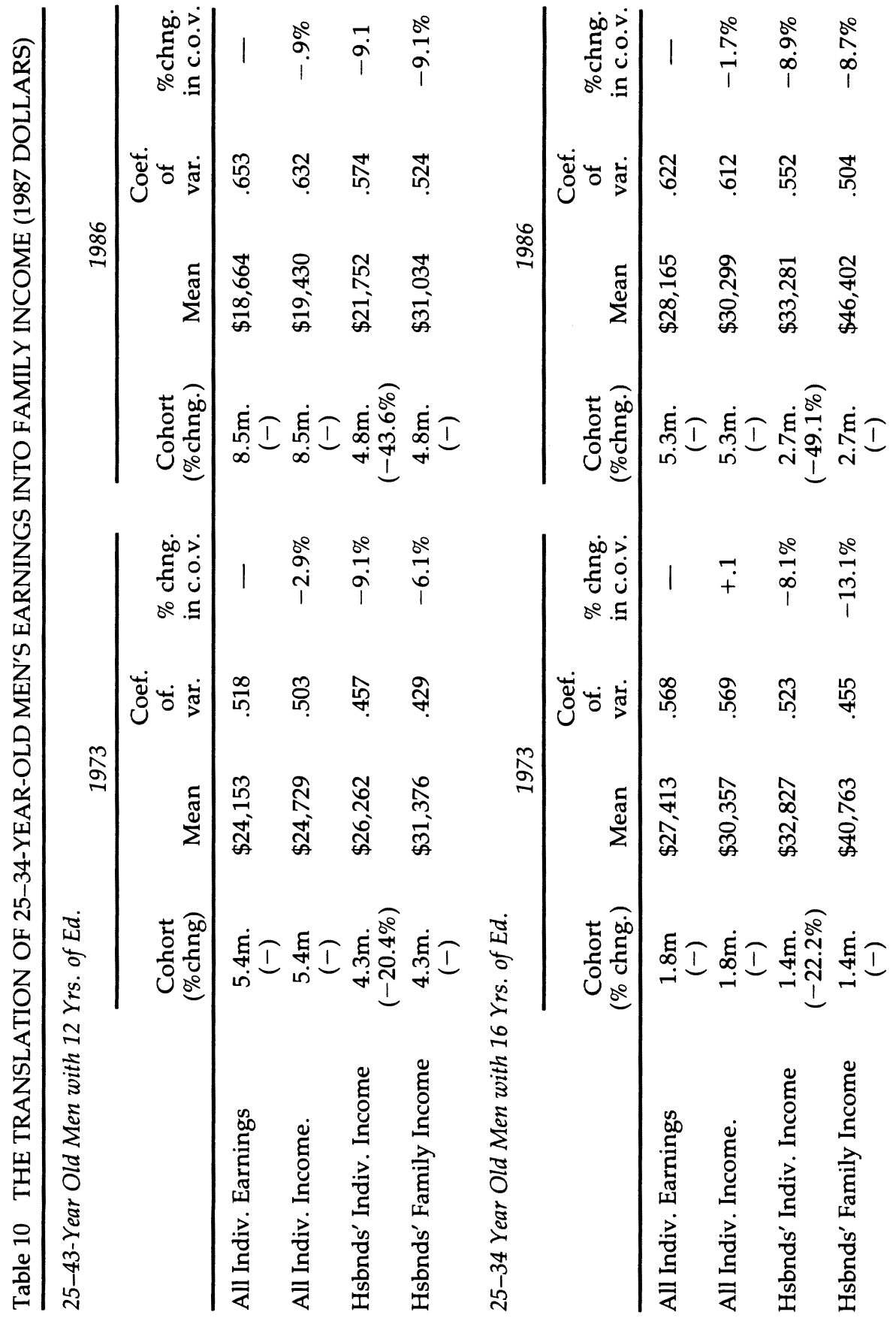




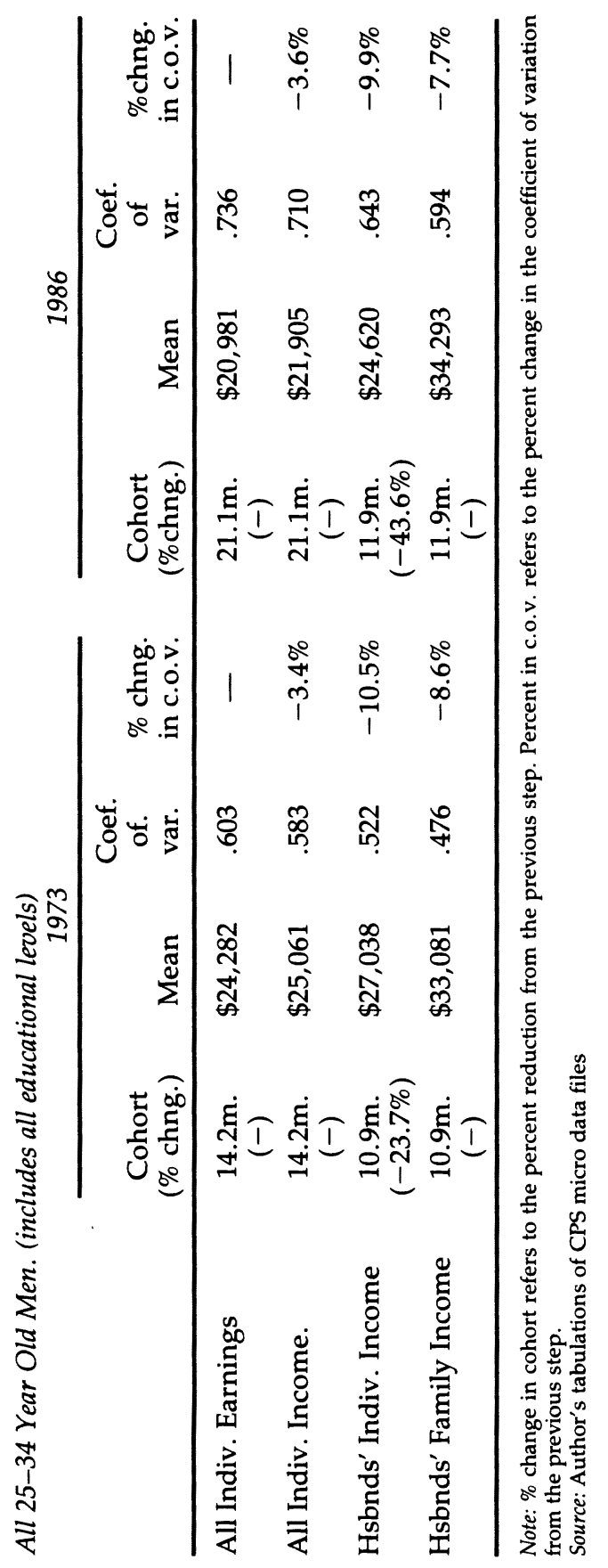


argues that the prominence of female-headed families among blacks reflects a pool of black "marriageable men" that has been sharply limited by unemployment and low earnings (as well as incarceration and homicide). Wilson offers some suggestive evidence on this proposition (Wilson 1988) while other attempts to test the proposition do not reach clear conclusions (e.g., Bassi 1987).

\section{Conclusion}

It is sometimes argued that the income distribution is the preoccupation of intellectuals: the population at large does not care about it, and if the government cares about it, it should not since it will only make things worse. ${ }^{53}$ People can argue about the normative content of this view, but as a description of behavior, it is increasingly incorrect. In recent years, the distributions of U.S. earnings and family incomes have increasingly been the subject of public discussion. There are, I believe, two reasons why this trend will continue. The first reason involves the ramifications of continued slow growth of individual incomes (should growth, in fact, remain slow). With the conspicuous exception of Social Security, the U.S. has not engaged in significant income redistribution to reduce inequality. Rather, we have relied on rapid economic growth to improve living standards across the board. This is a sensible enough strategy when growth is strong but it leaves us vulnerable when growth is weak. Today, for example, something like half of all 25-34-year-old men have a high school diploma or less. If this group has greatly difficulty in buying single family homes-in particular, more difficulty than their fathers had-this economic issue will surely become a political issue as well.

The second reason for predicting continued attention is the growing bi-modality in the distribution of children's families' incomes (Figure 7). Through much of the 1970s, the labor force was growing at $2-2.5 \%$ per year and labor with weak skills could simply be disregarded. Over the next decade, the labor force will be growing at $1-1.5 \%$ a year and labor will become a relatively scarce commodity. It is very hard to predict the required skill distribution of future occupations, but it is plausible that many occupations will require more skills in the future than they did in the past. A number of recent newspaper articles and anecdotes have described the growth of applicant testing for automobile production workers (particularly at U.S.-Japanese joint ventures), telephone operators, and other "good high school jobs" (Levy and Murnane, forthcom-

53. This spirit is captured in Irving Kristol's comment on Alan Blinder's 1980 review of income inequality (Kristol 1980). 
ing). In this context, the growing proportion of children in homes with incomes less than $\$ 10,000$ is not a good sign. Sarah McLanahan (1985), among others, has demonstrated that coming from a low income, female headed family sharply increases the probability of not finishing high school for both whites and blacks. The implications of this situation have already stimulated both substantial public discussion and growing business interest in assisting local school systems. ${ }^{54} \mathrm{~A}$ decade ago, when the labor force was increasing at $2-3 \%$ per year, such cooperation was largely unknown.

In sum, issues of inequality are very much today in the public eye. I believe they have reached that position as much from a failure of growth as from increased inequality per se. But whatever their origins, the issues will be with us for the foreseeable future.

\section{REFERENCES}

Baily, Martin Neil and Robert J. Gordon. 1988. "The Productivity Slowdown, Measurement Issues, and the Explosion of Computer Power." Brookings Papers on Economic Activity. 1988. No. 2., pp. 347-421.

Bane, Mary Jo and David T. Ellwood. 1986. "Slipping In and Out of Poverty: The Dynamics of Spells." Journal of Human Resources, 21, No. 1. Winter. pp. 1-23.

Bassi, Lauri, J. 1987. "Family Structure and Poverty Among Women and Children: What Accounts for the Change," Georgetown University. Mimeo. June.

Bianchi, Suzanne M. and Daphne Spain. 1986. American Women In Transition. New York: The Russell Sage Foundation.

Blackburn, McKinley, David Bloom, and Richard B. Freeman. 1988. "Why has the Economic Position of Less-Skilled Male Workers Deteriorated in the United States?" Paper presented at the Brookings Institution Conference on Future Job Prospects. March 1989.

Blanchard, Olivier J. and Lawrence H. Summers. 1986. "Hysteresis and the European Unemployment Problem." National Bureau of Economics Research Macroeconomics Annual. Cambridge, Mass.: MIT Press. 1986. pp. 15-78.

Bluestone, Barry and Bennett Harrison. 1986. "The Great American Job Machine: The Proliferation of Low-Wage Employment in the U.S. Economy." Study prepared for the Joint Economic Committee of the U.S. Congress. Washington, D.C. December.

Brookes, Warren T. 1987. "Low-Pay Jobs: The Big Lie." The Wall Street Journal (oped). March 25, 1987.

Butz, William P. and Michel P. Ward. 1979. "The Emergence of CounterCyclical U.S. Fertility." American Economic Review. 69 (June), pp. 318-28.

Coder, John, Lee Rainwater, and Timothy Smeeding. 1988. "Inequality Among Children and Elderly in Ten Modern Nations: The U.S. in an International Context." Paper prepared for the American Economic Association Meetings, New York, December.

54. I am thinking here of the Boston Compact and corporate-school ventures in Houston, Cleveland and elsewhere. The Philadelphia firm Public Private Ventures is currently evaluating a number of projects of this kind. 
Children's Defense Fund. 1988. A Call for Action to Make Our Nation Safe For Children: A Briefing Book on the Status of American Children in 1988. Washington, D.C.

Council of Economic Advisers. 1985. The Economic Report of the President, 1985. Washington, D.C.: GPO, January.

Council of Economic Advisers. 1988. The Economic Report of the President, 1988. Washington, D.C.: GPO, February.

Council of Economic Advisers. 1989. Economic Report of the President, 1989. Washington, D.C.: GPO, January.

Dennison, Edward F. 1985. Trends in American Economic Growth, 1929-82. Washington, D.C.: The Brookings Institution.

Easterlin, Richard. 1980. Birth and Fortune. New York: Basic Books.

Elster, Susan and Mark S. Kamlet. 1987. "Income Aspirations and Married Women's Labor Force Participation." Pittsburgh: Carnegie Mellon University. Mimeo. September 21, 1987.

Freeman, Richard B. 1976. The OverEducated American. New York: Academic Press.

Fuchs, Victor. R. 1968. The Service Economy, New York: National Bureau of Economic Research and Columbia University Press.

Fuchs, Victor. R. 1988. Women's Quest for Economic Equality. Cambridge, Mass.: Harvard University Press.

Gans, Herbert. 1967. The Levittowners, New York: Pantheon Books.

Gottschalk, Peter, Sheldon Danziger, and Eugene Smolensky. 1988. "Recent Developments in the Upper Tail of the Income Distribution." Paper prepared for the Annual Meetings of the American Economic Association. New York City, December.

Horvath, Francis W. 1987. "The Pulse of Economic Change: Displaced Workers 1981-85." Monthly Labor Review. July, pp. 3-12.

Katz, Lawrence F. and Lawrence H. Summers. 1988. "Can Inter-Industry Wage Differentials Justify Strategic Trade Policy?" National Bureau of Economic Research. Mimeo. April.

Kendrick, John. 1984. "The Implications of Growth Accounting Models." In The Legacy of Reaganomics: Prospects for Long Term Growth, Charles R. Hulten and Isabel V. Sawhill. eds. Washington, D.C.: The Urban Institute Press.

Kosters, Marvin H. and Murray N. Ross. 1988. "A Shrinking Middle Class?" The Public Interest, No. 90, Winter 1988, pp. 3-27.

Kristol, Irving, 1980. "Comment" [on Alan Blinder's Chapter] in Martin Feldstein, ed. The American Economy in Transition, National Bureau of Economic Research and University of Chicago Press.

Kuttner, Bob. 1983. "The Declining Middle." Atlantic. July 1983, pp. 60-72.

Lawrence, Robert Z. 1982. Can America Compete? Washington, D.C.: The Brookings Institution.

Lawrence, Robert Z. and Charles L. Schultze, eds. 1987. Barriers to European Growth: A Transatlantic View. Washington, D.C.: The Brookings Institution.

Levy, Frank. 1979. "On Understanding Proposition 13." The Public Interest. Summer.

Levy, Frank. 1988a. Dollars and Dreams: The Changing American Income Distribution. New York: W. W. Norton.

Levy, Frank. 1988b. "Incomes, Families, and Living Standards." Ch. 5 in Rob- 
ert E. Litan, Robert Z. Lawrence, and Charles L. Schultze, eds. American Living Standards: Threats and Challenges. Washington, D.C.: The Brookings Institution.

Levy, Frank and Richard C. Michel. 1987. "Understanding the Low Wage Jobs Debate." The Urban Institute. Mimeo.

Levy, Frank and Richard J. Murnane. 1989 Forthcoming. "Jobs, Demography, and the Mismatch Hypothesis." University of Maryland School of Public Affairs Working Paper.

Lillard, Lee, James P. Smith, and Finis Welch. 1986. "What Do We Really Know about Wages?" Journal of Political Economy. 94, No. 3. June, pp. 489-506.

Litan, R.E., Lawrence, R.Z., and Schultz, C.L. (eds.) 1988. American Living Standards: Challenges and Threats. Washington, D.C., The Brookings Institution.

Maddison, Angus. 1987. "Growth and Slowdown in Advanced Capitalist Economies: Techniques of Quantitative Assessment." Journal of Economic Literature Vol. xxv. June, pp. 649-98.

McClanahan, Sara S. 1985. "Family Structure and the Reproduction of Poverty." American Journal of Sociology. 90, No. 4, pp. 873-901.

Murphy, Kevin and Finis Welch. 1988. “Wage Differentials in the 1980s: The Role of International Trade." Paper presented at the Mont Pelerin Society General Meeting, September 9.

Norwood, Janet. 1987. "The Job Machine Has Not Broken Down." The New York Times, February 22, Section F, p. 3.

Rosenthal, Neal H. 1985. "The Shrinking Middle Class: Myth or Reality?" Monthly Labor Review. March, pp. 3-10.

Samuelson, Robert J. 1987. "The American Job Machine." Newsweek. February 23, 1987.

Sawyer, Malcolm. 1976. "Income Distribution in OECD Countries." Paris: OECD Occasional Studies. July.

Schumpeter, Joseph. 1942. Capitalism, Socialism and Democracy. New York: Harper.

Smith, James P. and Michael P. Ward. 1984. Women's Wages and Work in the Twentieth Century, Santa Monica: Rand Corporation.

Sum, Andrew and Neal Fogg. 1987. "Trends in Real Earnings and Incomes of Young Males in the U.S.: 1967-1985." Northeastern University, Center for Labor Market Studies Working Paper. 1987.

U.S. Bureau of the Census. 1987a. "Martial Status and Living Arrangements." March 1986. Current Population Report, Series P-20, No. 418, Washington, D.C.: Government Printing Office.

U.S. Bureau of the Census. 1987b. "Money Income of Households, Families and Persons in the United States, 1986." Current Population Reports, Series P-60, No. 159, Washington, D.C.: Government Printing Office.

U.S. Congressional Budget Office. 1987. "The Changing Distribution of Federal Taxes: 1975-1990." (authored by Richard Kasten and Frank Sammartino). Washington, D.C.: Government Printing Office.

U.S. Department of Commerce. 1988. Statistical Abstract of the United States, 1988. Washington: Government Printing Office.

Thurow, Lester C. 1984. The Disappearance of the Middle Class. New York Times, February 5, Section 3, p. 2.

Wilson, William J. 1988. The Truly Disadvantaged. Chicago: University of Chicago Press. 


\section{Comment}

\section{LAWRENCE H. SUMMERS}

Frank Levy's impressive paper is largely about the 535 electoral vote question of whether peoples are better off today than they were 16 years ago, or even 8 years ago. Levy's verdict is fairly negative, and is all the more worrisome because it reflects extensive and thorough contact with the data. The American people gave an answer to that question in the November 1988 election-a somewhat more optimistic answer than Levy provides in his paper. Some of my friends and I wish we knew why. I can however offer some observations on Levy's analysis.

First, have living standards really stagnated as badly as the official statistics Levy relies on suggest? There is a kind of disjunction in professional discussions. Had this been a paper called "The Productivity Slowdown" and had it been claimed that productivity had been growing rapidly up until 1973 and stopped growing rapidly thereafter, lengthy discussion of whether the productivity statistics are right would ensue. The issues of whether we measure the quality of goods appropriately and whether we measure improvements in the service sector at an appropriate rate would be debated. Such issues are not usually aired when the subject is the behavior of real wages or family incomes. Yet, they are equally fundamental even when productivity is not the proximate issue. The same price deflators that need to adequately treat quality change in evaluating productivity performance are also crucial components of the price indexes used to study trends in real wages or family incomes. To whatever extent quality measurement issues are important in discussing productivity, they are equally important in discussing stagnation in measured real income growth.

Think of some examples. You can get money from your bank at midnight, when once you could not. You can get a boarding pass before you fly. Perhaps more consequentially, in a world where the average American family has a TV set on for 50 hours each week, you can now choose from $90 \mathrm{TV}$ channels, and you used to be able to choose from only three or four. You can cook in your microwave. Your supermarket has twice as many goods to choose from as it did fifteen years ago. It is probably true that none of those developments are reflected to an appreciable extent in our measure of increases in standard of living, and for that reason, the thesis of stagnation is overstated,

How serious are these biases? It is very hard to get a sense of what their overall magnitude is. Let me suggest one crude criterion. These 
types of developments that I have been describing have been universal, taking place around the world. If you use the numbers we conventionally use-the conventional time series numbers of productivity or on quality-and you make international comparisons, what you conclude is that the standard of living in Britain or Japan today is roughly comparable to standards of living in the United States at the end of World War II in the case of Britain and in the early 1950s in the case of Japan. If you think this is true, then it follows that you arrive at the conclusion that this quality problem is not serious. If you think that life in Japan is rather better than life in the United States in the early 1950s, you are drawn to conclude that our statistics in the United States have understated the growth in standards of living over time. I think that is almost certainly the case.

Whether or not that any of this explains the productivity slowdown is of course a very different question. While I can not produce as good a list of new innovations that took place between 1960 and 1973 that would have increased standards of living as I can between 1973 and the present, I suspect that has more to do with the fact that I was six years old in 1960 than it does with those innovations not having taken place. On balance, I think there are strong reasons to believe that real income growth is greater in the United States than official statistics suggest. Whether official statistics correctly portray its deterioration is much less obvious.

Second, I think that the political and the op-ed discussions of standards of living issue have introduced two sets of verbiage into the discussion of the change in the distribution of standards of living which are not helpful. I would have liked to see Levy go after these ideas more forcefully. One is the notion of the vanishing middle class. One might think, having heard that the middle class had disappeared or had diminished or was vanishing, that there would be some distribution of something relevant that would be bimodal. But this is not the case. All of the distributions-skill, wages, income, everything under discussion in Levy's paper-are not bimodal. They are single peaked. That single peak is very near their middle. That was true, and continues to be true.

Discussions of the disappearance of the middle class have more to do with the way in which we define the middle than it does with factors that are more economically meaningful. This is not to deny that there have been increases in inequality, but I think discussing them in terms of a declining middle class is unhelpful. It leads to the rather sorry spectacle of debates between the Wall Street Journal and The New York Times over whether the middle class has diminished because of an increase in the size of the upper class or an increase in the size of the 
lower class. Given the likelihood that 20 percent of the population will continue to be in the top fifth of income distribution, this type of discussion is less than fruitful.

I am also skeptical, though to a slightly lesser degree, about those discussions of living standards that focus on the "good jobs" versus "bad jobs" distinction. Real wages in all jobs have increased much more slowly since 1973 than they had prior to 1973. There have been movements in the employment structure which have moved to some extent between higher wage jobs and lower wage jobs, but those are very much second order relative to the common movement in all jobs.

Furthermore, there is a minimal need to determine how much of any change that has taken place in the distribution of good and bad jobs, and what this has to do with the change in the distribution of good and bad workers as opposed to good and bad jobs. If, as in recent work on industry wage differentials, an effort is made to control for differences between jobs in worker characteristics and to isolate something that is maybe a pure characteristic of jobs, the significance of the movements in the income distribution that are due to movements between good and bad jobs is substantially reduced.

My third observation is that it is time for the literature on the changing American wage structure to move from description toward explanation. Levy's paper is entirely persuasive (subject to the measurement qualification noted above) on the point that wage growth has slowed and that more skilled workers have gained at the expense of less skilled workers. Forecasts of the future and judgments about policy depend on the explanation of these phenomena.

I would distinguish two hypotheses which I hope will be contrasted in future wage structure research. The macroeconomic hypothesis links increasing inequality and to some extent slow wage growth to transitory macroeconomic developments. It is a very optimistic viewpoint. According to the macroeconomic view, macroeconomic policies that have pushed the dollar up in the early 1980s and led to deindustrialization are the culprit. This view paints a bright picture for the 1990s.

It is a near certainty that the rest of the world will not continue loaning us money at current rates, so the trade deficit will have to fall. Since manufacturing accounts for 80 percent of U.S. trade, this portends the reindustrialization of America. Recognizing that our trade deficit is nearly 3 percent of GNP and that some deterioration in our terms of trade is nearly inevitable, it is hard to escape the conclusion that manufacturing as a share of GNP will have to raise by 3 to 4 percent in the 1990s. For this to happen by 1995, manufacturing would have to grow more than twice as rapidly as the aggregate economy over the next five 
years and the share of manufacturing in the American economy would have to reach a record level.

The reindustrialization of America would create opportunities for the kinds of workers who were displaced during the early 1980s, and would no doubt increase the demand for brawn relative to brains. If the macroeconomic disturbances of the 1980s caused increases in inequality during the last decade, then the 1990s will see inequality come down.

A different macroeconomic determinant of the wage structure is the degree of pressure in labor markets. Observing what we pay our cleaning woman, I cannot help but think that in an economy that has very low unemployment, in an economy where for some set of macroeconomic reasons there is a shortage of labor, the return to unskilled labor increases quite rapidly. The average unemployment rate over the 16 year period since 1973 has been considerably greater than the average unemployment rate in the sixteen years preceding 1973. The post-1973 period has seen two very serious recessions, and I wonder whether that does not have something to do with the change in the return to different types of workers that Levy discusses in his paper.

Some variant on the macroeconomic hypothesis is relatively conventional wisdom. The alternative hypothesis, which is vigorously urged by Robert Reich, Barry Bluestone, Bennett Harrison, and some other progressive critics of mainstream economic thinking, stresses structural determinants of the wage structure. This view is less optimistic than the macroeconomic viewpoint since it highlights changes in the world economy that will not be reversed as the U.S. trade deficit diminishes.

Three structural stories can plausibly be linked to the changing wage structure. First, the combination of continuing political harmony and technical change are integrating the world economy at a rapid ratewitness the doubling in the share of trade in the U.S. economy over the last 30 years. Trade theory teaches us that trade in goods and factor mobility are substitutes. The rest of the world is longer on brawn than on brains and longer on unskilled workers than on skilled workers. It stands to reason that increased trade volumes will therefore benefit skilled workers at the expense of unskilled workers. This is not just theory. My recent work with Larry Katz (1989) demonstrates that the workers in U.S. export industries are more skilled and paid more than workers in U.S. import industries.

This story clearly works in the right direction for explaining increased inequality. It also suggests no respite in the years to come. The question is whether it is quantitatively important enough to account for the change in inequality given that trade is still relatively small compared to the entire economy. 
A second structural explanation for increasing inequality is that the impact of technological changes such as computerization has been to increase the return to being skillful. A single consultant can visit many more companies in a year than was once the case. Managers can now dispense with support staffs when computers can collate and process data. As product variety increases, the return to a salesman's being smart as well as personable is increased. Such effects are difficult to quantify, but may nonetheless be important to determining the wage structure.

There is a third structural explanation for increasing inequality-one that is very difficult to test. It may be that as the world has become a tougher, more competitive place, horizontal equity norms have given way to more ruthless systems of pay for performance. This may be because relatively egalitarian wage structures are luxuries that can no longer be afforded. Or it may be because the importance of providing workers with incentives to do a good job has increased. Consider some examples. Companies are starting to make much more use of profitsharing and bonuses. Law firms are increasingly compensating partners on the basis of performance, not seniority. And companies are being much more ruthless about eliminating redundant middle managers. This trend, like the other structural factors I have cited, is unlikely to reverse itself.

Is the macroeconomic or the structural view of increasing inequality correct? I am not sure. The structural arguments strike me as more compelling than the macroeconomic ones. On the other hand, many more structural breaks with our economic past are proclaimed than actually take place. Only time and future research (in that order I fear) will resolve the issue.

Let me turn finally to the two policy inferences that are drawn by Levy in his conclusions. The first is that if we are no longer growing we will have to worry more about redistribution. The exact meaning of the phrase "we will have to" is not clear. I would guess as a predictive theory that if we are not growing it will make us less likely to worry about redistribution rather than more likely. Generosity is almost certainly a luxury good. It is not an accident that the Great Society emerged in the 1960s, at the tail end of a boom, supported by projections of very generous growth that made it look like you could do almost anything and have it cost a relatively modest amount.

If we are to grow slowly, and if it is to be the case that the least skilled one-third of the population will have a difficult time earning a substantial income, redistribution on a scale where it will reach everyone who does not go to college, or will reach half the people who do not go to 
college, strikes me a being an exceedingly unlikely political and undesirable economic prospect. The more direct and appropriate policy response to tough times and widening inequality would not involve income redistribution so much as it would involve doing things that would affect the distribution of skills and doing things that would prepare a larger share of the population for better jobs.

Levy concludes by talking about what all this means for children, emphasizing the specter of poor children falling further and further behind. He may be right, but I would say the evidentiary content of this part of his paper is rather low. First of all, even granting that children in poor families do worse than children who come from more affluent families, it does not follow that transfering income to the poor families and making them no longer poor will solve whatever is giving rise to that correlation. That does not follow and is not really argued in the paper. Without knowing what it is that has taken place that has caused the changes in the income distribution of children, one cannot really support the conclusion that more income redistribution will equalize the distribution of skills among the nation's children.

Furthermore, I suspect that in order to really understand what has happened to the distribution of income among children, one would have to pay more attention than the paper does to changes in the patterns of fertility across different groups in the population. The fact is that, contrary to myth, the number of children being born under the poverty line or near the poverty line has not increased during the 1970s. A large part of what has happened is that fertility has just collapsed among those far above the poverty line. That is responsible for some significant part of the increase in the fraction of kids below the poverty line.

Frank Levy's paper has done an excellent job of describing the American economy's most serious problems. I hope and trust that his future research and that of others will go further and point toward explanations for the unfortunate trends he describes. Only after sound explanations have been provided will one be in a position to offer convincing policy recommendations.

\section{Discussion}

Robert Hall felt that Levy's evidence indicated that the US economy is becoming more meritocratic. Though dropouts are important at the lower end of the income distribution, Hall speculated that the rest of the income distribution was largely determined by ability. Levy responded 
that it was important to keep in mind the large distributional effects of macroeconomic events such as the large trade deficits. Murphy added that while changes in wages are in part due to changes in the supply of labor, the most important factor in changing wage distributions, particularly among the poor, is changing labor demand. This is reflected particularly in the return to higher education.

Robert Gordon took issue with Summers' skepticism about the degree of nominal wage rigidity. If jobs are changing through time, average wages will change even if no individual wages change. Gordon also wondered whether today's high pressure economy, with its increased demand for high-wage manufacturing goods will help the poor as much as past expansions, based more on low-wage output. Finally, Gordon suggested that income distribution may be determined more by the compensation institutions in a country than by any sense of meritocracy, citing the tighter Japanese distribution over the US one. Hall responded that the United States has a more diverse population than many other countries so that it was not right to compare income distributions.

William Nordhaus found puzzling Murphy's evidence that wages for older workers seem more flexible than wages for younger workers. William Brainard suggested that this may be due to differences in working positions for the two groups. Nordhaus also indicated that college admission was still largely restricted to the upper income distributions, suggesting that family characteristics may be as important as merit in advancement.

Mark Bils suggested that Levy control for cost of living changes in different regions of the country. Levy indicated that this was difficult to do because the cost of living varied even within regions.

Levy concluded by emphasizing that aggregate wage stagnation makes relative income changes more important than they are when wages are growing, and that just as it is difficult to explain the productivity slowdown with changes in the quality of output, it is difficult to believe that people are better off because of an increased quality of the goods they purchase. 